NBER WORKING PAPER SERIES

\title{
OPTIMAL CURRENCY SHARES IN INTERNATIONAL RESERVES: THE IMPACT OF THE EURO AND THE PROSPECTS FOR THE DOLLAR
}

\author{
Elias Papaioannou \\ Richard Portes \\ Gregorios Siourounis \\ Working Paper 12333 \\ http://www.nber.org/papers/w12333 \\ NATIONAL BUREAU OF ECONOMIC RESEARCH \\ 1050 Massachusetts Avenue \\ Cambridge, MA 02138 \\ June 2006
}

We thank Takatoshi Ito, Takeo Hoshi, Shin-ichi Fukuda, Andrew Rose, Philip Hartmann, J. Onno de Beaufort Wijnholds, Hélène Rey, Harris Dellas, participants in the TRIO (NBER-TCER-CEPR) conference and seminars at the European Central Bank, the Hong Kong Institute for Monetary Research, Bilkent University, Eurobank, the Bank of Japan, and the Bank of Spain for useful comments and suggestions. We also benefitted from detailed suggestions and feedback from three anonymous referees. All errors are ours. The views expressed are the authors' and do not reflect those of the European Central Bank or the Eurosystem. The views expressed herein are those of the author(s) and do not necessarily reflect the views of the National Bureau of Economic Research.

(C)2006 by Elias Papaioannou, Richard Portes and Gregorios Siourounis. All rights reserved. Short sections of text, not to exceed two paragraphs, may be quoted without explicit permission provided that full credit, including () notice, is given to the source. 
Optimal Currency Shares in International Reserves: The Impact of the Euro and the Prospects for the Dollar

Elias Papaioannou, Richard Portes and Gregorios Siourounis

NBER Working Paper No. 12333

June 2006

JEL No. F02, F30, G11, G15

\begin{abstract}
Foreign exchange reserve accumulation has risen dramatically in recent years. The introduction of the euro, greater liquidity in other major currencies, and the rising current account deficits and external debt of the United States have increased the pressure on central banks to diversify away from the US dollar. A major portfolio shift would significantly affect exchange rates and the status of the dollar as the dominant international currency. We develop a dynamic mean-variance optimization framework with portfolio rebalancing costs to estimate optimal portfolio weights among the main international currencies. Making various assumptions on expected currency returns and the variance-covariance structure, we assess how the euro has changed this allocation. We then perform simulations for the optimal currency allocations of four large emerging market countries (Brazil, Russia, India and China), adding constraints that reflect a central bank's desire to hold a sizable portion of its portfolio in the currencies of its peg, its foreign debt and its international trade. Our main results are: (i) The optimizer can match the large share of the US dollar in reserves, when the dollar is the reference (risk-free) currency. (ii) The optimum portfolios show a much lower weight for the euro than is observed. This suggests that the euro may already enjoy an enhanced role as an international reserve currency ("punching above its weight"). (iii) Growth in issuance of euro-denominated securities, a rise in euro zone trade with key emerging markets, and increased use of the euro as a currency peg, would all work towards raising the optimal euro shares, with the last factor being quantitatively the most important.
\end{abstract}

Elias Papaioannou

European Central Bank

DG-R; Financial Research (EM 1623)

Postfach 160319

D-60311 Frankfurt

GERMANY

elias.papaioannou@ecb.int
Gregorios Siourounis

Barclays Capital

5 The North Colonnade

Canary Warf

London E14 4BB

UNITED KINGDOM

gsiourounis@london.edu

Richard Portes

London Business School

Regent's Park

London NW1 4SA

UNITED KINGDOM

and NBER

rportes@london.edu 


\section{Introduction}

The euro has been in existence for seven years, and euro notes and coins have been in circulation for four years. Although it is still premature to evaluate the full implications of the only major currency established for more than a century, its successful introduction has already brought significant consequences for international finance. For example, a growing number of firms and sovereigns raise external finance issuing euro-denominated securities. The use of the euro as a currency for the settlement or invoicing of international trade transactions has also shown a notable increase in recent years (ECB, 2005). There is concern that portfolio shifts from dollar-to euro-denominated assets, in particular, by central banks, could result in a sharp appreciation of the euro relative to the dollar. And a key question among politicians, academics, and the public is whether the euro will challenge or eventually displace the dollar as the leading international currency.

The prospects of big portfolio shifts from the dollar to the euro and the euro taking on some of the dollar's roles in the international financial system seemed unlikely a decade ago, when the first stages of European Monetary Union were designed. Some did argue that the euro could achieve the prerequisites for a major international currency (Alogoskoufis and Portes, 1991, 1992, 1997; Portes and Rey, 1998; Bergsten, 1997) and considered the consequences for international portfolio allocation and exchange rates. The dominant view, however, held that the euro's international impact would be small (e.g., Frankel, 1995; Eichengreen, 1998) or that the expansion of its role would be very slow (Hartmann, 1998a,b). Indeed, many were sceptical even about its legal and technical foundations, its short- to medium-term viability in the face of currency market pressures and its long-run impact inside Europe (e.g., Feldstein, 1997). Those who doubted that the euro would be successful stressed that the Eurozone was not an "optimal currency area" and could therefore lead to tensions among member states in the conduct of monetary policy. Moreover, the non-unified political voice of Europe would impede the euro's internationalization. Its role would be little more than that of the Deutsche mark - both theory (network externalities, e.g., Rey, 2001) and history (dollar and sterling, e.g., Eichengreen, 2005) suggested great inertia in the international status of currencies. The incumbent dollar was so dominant that only a cataclysmic shock could threaten its hegemonic status.

Now, however, the prospect that the euro will at least challenge the dollar's role in global markets sounds less implausible. The euro zone is comparable with the American economy 
in terms of GDP and trade openness, and it may even become larger when non-eurozone EU members join in. The European Central Bank (ECB) has kept inflation expectations low, minimizing fears that it might abandon the anti-inflationary tradition of the "core" countries. Perhaps most important, the rising current account deficit and external debt of the United States create pressure on the dollar. In a recent survey of central banks (RBS, 2005), most respondents said that they intended further diversification away from the dollar, due to their fear of a hard landing (Truman and Wong, 2006, discuss reserve diversification policies $)^{1}$. As the size of dollar-denominated external obligations rises, international portfolio holders perceive a rising "concentration risk" (Greenspan, 2004). On the other hand, the reluctance of the United Kingdom to adopt the euro and remaining obstacles to the full integration of euro-area government bond markets are both important negative factors for euro internationalization (Portes and Rey, 1998). In addition, although there has been a major transformation and expansion of euro zone securities markets since 1999, they are generally not yet as liquid and deep as in the US (Biais et al., 2006, Dunne et al., 2006).

This paper contributes to the ongoing policy and academic debate on the euro's international role by studying its effect on the composition of central banks' foreign exchange reserves. Although we focus here on only one feature of a currency's international use, reserve composition, our analysis will also touch on other interrelated dimensions. Examining international reserve holdings will lead us, for example, to consider how changes in the invoicing of financial and international trade transactions affect the composition of reserves. Foreign exchange reserves are just one of the international roles of currencies. This may be secondary to the vehicle currency role, which itself may rest on the standing of currencies in financial markets and the level of development of these markets. Yet there are very close links among these various roles (Kenen, 2003). Indeed, we find that the choice of reference currency, hence currency pegs (and the currency or currencies of foreign exchange market intervention) strongly influence the composition of reserves. Thus studying the effect of the euro on the composition of foreign exchange reserves may also bring new insights on other aspects of internationalization.

Although we do not consider the reserve accumulation decision (see European Central Bank, 2006), we note that one reason for looking now at the currency composition of foreign exchange reserves is their increasing importance in the international financial system.

\footnotetext{
${ }^{1}$ Russia, for example, announced on 8 June 2006 that it had shifted some of its reserves from dollars to euros and now holds 50\% USD, 40\% EUR, and 10\% GBP (Financial Times, 9 June 2006).
} 
Reserve growth in recent years has been dramatic. Figure 1 illustrates this. At the end of 2005 the stock of international reserves was 4.25 trillion dollars, having doubled in five years. The supply comes primarily from US current account deficits. On the demand side, this rapid accumulation comes from the emerging market and developing countries, which have tripled their reserves since the end of 1998. Current account surpluses in export-oriented developing countries have been supplemented by capital inflows. Emerging market economies have accumulated foreign assets as protection against financial crises and as a consequence of foreign exchange market intervention to prevent appreciation of their own currencies. In addition, the recent rise in oil and other commodity prices has increased foreign reserves in fuel-exporting countries, like Russia, Mexico and the Middle East. The expansion of reserves beyond minimum necessary levels offers central banks more flexibility in allocating them among currencies and types of assets.

The currency portfolio allocation of central banks with large reserves also affects exchange rates among major industrial countries (Blanchard et al., 2005) and is relevant to the recent debate on the sustainability of the U.S. current account (e.g., Gourinchas and Rey, 2005a,b; Obstfeld and Rogoff, 2005; Dooley, Folkerts-Landau and Garber, 2003, 2005; Roubini and Setser, 2005). Decisions by even a handful of central banks to shift their reserve composition away from the dollar could result in sizable dollar depreciation. Although many (notably Dooley et al, 2004, 2005) argue that Asian central banks with large reserves will not diversify away from the dollar, since they pursue an export-led growth strategy targeting the US market and will maintain exchange-rate stability relative to the dollar, even a limited shift out of dollar assets could result in sizable exchange rate movements. ${ }^{2}$

To assess the impact of the euro on international reserve holdings, we develop a dynamic mean-variance currency portfolio optimizer in a before-after event study framework. Using an optimizer that allows for dynamic correlations and serial dependence in the variancecovariance matrix of returns, and making various assumptions about currency returns, we obtain the optimal portfolio composition of central banks' foreign exchange reserves for the

\footnotetext{
${ }^{2}$ Such an adjustment need not occur abruptly. Former U.S. Treasury Secretary John Snow argued (13 January 2005) that diversification would be relatively small and would not have large implications for the dollar ("I think some diversification at the margin is certainly to be expected. I don't think it'll have any major ripples on our domestic markets."). Although this statement might just reflect optimism and desire to prevent a dollar run, there are surely factors suggesting that the rebalancing will occur gradually. First, the market closely observes how central banks manage their reserves. It is therefore quite difficult for a large central bank to rebalance quickly, since this might create excess volatility and trigger a crisis. Second, the euro zone authorities might be unwilling to let the euro appreciate sharply, with undesirable effects on euro zone competitiveness..
} 
eleven years surrounding the introduction of the euro in 1999. We study the five main international currencies, namely the U.S. dollar (USD), the euro (EUR), the Swiss franc (CHF), the British pound sterling (GBP), and the Japanese yen (JPY), to assess how the "optimal" share of the euro altered after 1999, compared to the optimal pre-1999 allocation to the three main euro predecessor currencies, the French franc (FFR), the Deutsche mark (DEM) and Dutch guilder (NLG).

We do this exercise for the "representative central bank", i.e. at the aggregate level, so we can compare these estimated optimal shares with the actual aggregate shares communicated by the International Monetary Fund in its Annual Report. Table 1 gives the IMF allocations of global reserves (those reported to the IMF). The data show an increase in the shares of both the dollar and the euro in recent years, notably at the expense of the yen and "Other Unclassified Currencies". Although the increase in the share of the euro is partly driven by its appreciation during 2002-2004 and changes in the IMF's methodology in compiling the data, since its introduction in 1999 the single European currency is gradually becoming more important, especially in the developing world. ${ }^{3}$

Central banks are unique institutions, however, and a simple mean-variance optimization that might look suitable for a global investor is clearly inappropriate. Anecdotal evidence, survey data and the scant empirics (reviewed in the next section) all suggest that a central bank needs to be highly liquid and will want to hold a sizable fraction of its reserves in the currencies of the country's main trading partners, in the currencies of its international liabilities, and if the domestic currency is pegged, in the currency or currencies of its peg. We therefore augment the currency optimizer with constraints reflecting these needs.

This approach has some nice features. The portfolio diversification methodology is both intuitive and theoretically driven (in a micro-founded International CAPM). Second, it is also consistent with what we observe (see Section 2). Central banks consult asset management experts and explicitly argue that maximizing returns (subject to their high risk aversion)

\footnotetext{
${ }^{3}$ The IMF has recently revised its methodology in compiling data on the currency composition of foreign reserves. Consequently the data are not fully comparable across years, since country coverage changes. In previously reported data, the IMF resorted to its own estimates, when countries were not reporting to its confidential database. The revised IMF data reflect a considerably smaller sample, since they are based only on reported data. Most importantly, since "reporting compliance" has traditionally been very low in Asia, the recent estimates do not include most East Asian economies. This is very important, since not only are these countries among the largest foreign reserve holders, but anecdotal evidence suggests that they overly invest in dollar assets. The recent ECB update on the International Role of the Euro (ECB 2005) provides details on the problems of the IMF data. Truman (2005b) presents data on reserve composition for 14 countries. Most show significant shifts from dollar and yen to euro from 2000 to 2004 .
} 
is one of their primary objectives. Some, like the Swiss National Bank, have hired external money managers to achieve higher returns. Other developing countries with large reserves, like South Korea and Singapore, have set up heritage funds to maximize actively the return on (part of) their reserves. In addition oil-exporting countries like Russia and Norway have set up specialized funds to manage their oil revenues, investing in various types of securities (even equity) to achieve diversification. Our methodology is flexible enough to allow us to add specific constraints reflecting the central banks' special needs. To represent their liquidity needs during periods of turmoil, we add portfolio rebalancing transaction costs, which we proxy with bid-ask spreads in the currency markets. In addition, when we look at specific countries, we augment the currency optimizer with constraints reflecting the desire of monetary authorities to hold a sizable fraction of their reserves in the currency of their main trading partners and the currency of government external liabilities. This methodology allows us to perform some simulations on the composition of a particular central bank's reserve holdings, given these special needs (constraints). Comparing the actual reserve composition (for example from aggregate IMF data or from central banks that report their portfolio holdings) and the allocations we obtain from the optimization gives us a rough measure of currency internationalization, a concept that is commonly used but rarely quantified.

Our results can be summarized as follows.

First, we find that since interest rates and especially exchange rates are very volatile, the mean-variance optimizer yields very unstable results when we assume a random walk of the exchange rate (i.e., expected currency returns equal the one-year interbank rate) or when we assume that central banks have perfect foresight regarding exchange rate movements. We thus present estimates assuming a weak version of uncovered interest parity (UIP), but also adding transaction costs of portfolio rebalancing. Even in this case, however, small changes either in currency returns or the variance-covariance matrix have non-negligible effects on the optimal portfolio weights. This result may explain the high inertia in reserve composition and rationalize why central banks proceed slowly when diversifying.

Second, we match the high allocation of the dollar in reserve holdings (about 60-65\%) when we use the US currency as the base-index or reference currency. Thus the high share of the dollar should not come as a surprise, given the fact that most central banks (even in industrial currencies) express their returns in dollar terms.

Third, regarding the other main international currencies, the optimizer yields allocations 
that significantly differ from actual (reported) reserve holdings. In particular, the meanvariance optimization framework yields roughly equal allocations to the four main currencies, and the optimal euro share is lower than what we observe. We regard this as evidence of the increasing international role of the euro, which leads to higher reserve holdings in euros than optimal portfolios would show. So far, however, this increased internationalization comes primarily at the expense of the yen, the pound sterling and the Swiss franc rather than against the dollar. An alternative interpretation would be that the euro's current role is for some unknown reason artificially high and will fall in the longer run. We regard this as implausible.

Fourth, the evidence suggests that during the past few years the spreads on transactions in the euro have fallen significantly (see Table 2). Spreads have also narrowed significantly for other industrial countries' currencies, thus making diversification away from the dollar more attractive. Although the traditionally low transaction costs in US currency and financial assets have been regarded as a key factor behind the dollar's international dominance, the optimal currency portfolios we calculate are not very sensitive to these costs. So this drop in spreads alone will not trigger a major switch away from the dollar. Our optimal portfolio estimates do not, however, incorporate the fact that spreads have also fallen significantly on transactions in euro-denominated securities, which would also favour a shift away from the dollar into the euro.

Fifth, we augment the currency optimizer with constraints capturing the desire of central banks to hold a sizable portion of their holdings in the currency of their external debt and in the trade invoicing currency, and we perform some simple simulations for four emerging market countries that have recently accumulated large amounts of foreign reserve assets: Brazil, Russia, India and China - the BRICs (Goldman Sachs, 2003, 2005). The constrained optimization results assign larger weights to the euro than the aggregate estimates (for the "representative central bank"), especially for Brazil and Russia. These simulations illustrate that the dominant position of the dollar might be challenged sooner than expected. This is because the euro zone is now the main trading partner of many emerging market countries (Russia, Brazil and India in our sample) that run large current account surpluses. In addition an increasing number of non-EU residents and governments issue euro-denominated assets. Still, when we incorporate transaction costs, the estimates with debt and trade constraints do not show the euro's share challenging that of the dollar. 
Sixth, we find that the reference currency, or the choice of risk-free asset, plays the most important role in determining the optimal composition of reserves in the mean-variance framework. But in practice, where there is a managed exchange rate regime, the reference currency is naturally the currency or currencies to which a country's own currency is pegged. This suggests that a major challenge to the dollar might come if more countries move away from managing their exchange rates with respect to the dollar and adopt euro-based anchors or basket pegs in which the euro has a high weight. This finding adds to previous literature on the determinants of foreign exchange reserve composition, by showing that quantitatively in a mean-variance framework the currency of the (de jure or de facto) peg is substantially more important than transaction costs, the direction of trade and the currency composition of external debt.

The paper is structured as follows. In the next Section, we review the evidence on what determines foreign exchange reserves. The lessons from history, the relatively few empirical studies, and survey and case-specific evidence are very consistent. Central banks do pay regard to the trade-off between returns and risk, and their reserve-holding behavior also reflects liquidity motives, the currencies of international trading and financing relationships, and the exchange-rate regime (currency peg). In Section 3 we describe our analytical framework. In Section 4 we present the results from the dynamic mean-variance analysis, making various assumptions about expected currency returns and using three different techniques to project the variance-covariance matrix of returns. We also perform various checks on the sensitivity and robustness of our results. In Section 5 we look at individual countries, incorporating the desire of central banks to hold a sizable fraction of their foreign exchange reserves in the currencies of their main trading partners, the currencies of their external debt and the anchor currency of the peg. In this context, we present some portfolio optimizations for the BRICs. In Section 6 we summarize.

\section{Related literature on the currency composition of foreign reserves}

\subsection{History}

Those who see a growing international role for the euro point out that history provides examples of leading international currencies losing their dominant status or of sharing inter- 
national status (see Lindert, 1969). Most recently, during the gold standard era, the pound sterling enjoyed a dominant international role similar to that of the dollar since the early fifties. Yet both economic policies and the two world wars weakened the British economy and its external finances, and the dollar replaced sterling as the leading international currency. The development of the New York financial markets in the 1920s and the establishment of the Federal Reserve System were also major factors in the rise of the dollar. Hartmann (1998) and Eichengreen (2005) point out that although some theoretical analyses based on network externalities in the use of money for transactions suggest that there will be only one international currency, this argument does not apply to the currency of denomination of reserves. This is because the need for diversification forces private agents and central banks away from only one currency. ${ }^{4}$ History also suggests that the primary considerations for the composition of reserves have been market liquidity (which in turn depends on central banks' willingness to ensure it, currency convertibility, financial stability, and the underlying development of financial markets) and a dominant position in international trade. Yet besides these economic reasons, geopolitical factors are also important. Sterling's internationalization occurred after the United Kingdom established itself as an imperial power, while the dollar ascended after the United States emerged as the dominant military power.

\section{$2.2 \quad$ Regression evidence}

Large-sample evidence on the determinants of reserve composition based on regression techniques is scant. Attempts to address this question directly by regressing actual currency shares on macroeconomic, monetary and financial factors are hampered by the reluctance of central banks to release data on the currency composition of reserves.

In a recent paper, Chinn and Frankel (2005) use aggregate IMF data (similar to those presented in Table 1) on the shares of seven main currencies in total identified official reserve holdings during the 1973-1998 period to investigate determinants of the global composition of international reserves. Their main finding is that the shares of major currencies in global reserve holdings are very persistent (the coefficient on the lagged dependent variable is between 0.85 and 0.96). In addition, the lagged depreciation rate and inflation (or exchange rate volatility) enter with negative and significant coefficients, while income enters with a

\footnotetext{
${ }^{4}$ Eichengreen (2005) writes that "It may pay to hold reserves in the most liquid market, which tends to be the market in which everyone else holds reserves, but market liquidity is not all that matters. It may worth tolerating a bit less market liquidity in return for the benefits of greater diversification..."
} 
significantly positive coefficient. ${ }^{5}$ Chinn and Frankel also perform an out-of-sample forecast and compare it with the actual (reported) realized share of the euro. Their projections suggest that it will take at least 25 years for the euro to challenge the dominance of the dollar as a major reserve currency, unless there is a major deterioration in the stability of the dollar (depreciation, inflation).

Although this approach is informative, it is not fully reliable mainly due to non-trivial data problems. First, besides the IMF data limitations discussed earlier (footnote 3), the analysis is based on aggregate global data. The IMF does not provide data from individual central banks. Although the IMF also provides a disaggregation between industrial and developing countries, this separation is again coarse. Moreover, the more reliable data from the industrial group are not fully suitable, since these countries cannot hold their own currencies as reserves. On the other hand, data for developing countries, which are more appropriate to judge the international role of currencies, are recorded with substantial error (ECB 2006). ${ }^{6}$ Second, the extrapolation procedure implicitly assumes that the same dynamics govern the composition of reserves before and after the introduction of the euro. Yet the introduction of the euro has probably changed exchange rate dynamics. Third, as the authors acknowledge, most of the forecast is generated by the lagged dependent variable, while the most interesting question would be to understand what drives this huge persistence (see also Truman, 2005a, on this point). ${ }^{7}$ This high inertia is consistent with our optimization results. Optimal allocations are quite sensitive to even small changes in expected returns and the variance-covariance structure. We believe this explains at least part of the unwillingness of central banks to rebalance their portfolios quickly.

Dooley, Lizondo and Mathieson (1989) and more recently Eichengreen and Mathieson (2000) utilized confidential IMF data on shares of the major international currencies in reserve holdings in a large number of industrial and developing countries to investigate the high persistence. Although there are still data problems here, both studies find that currency pegs, the direction of trade, and the currency of foreign debt can explain the high inertia in

\footnotetext{
${ }^{5}$ Eichengreen and Frankel (1996), Eichengreen (1998) and Chinn (1999) reach similar results in slightly different samples.

${ }^{6}$ For a similar point see Chinn and Frankel (2005) and Eichengreen and Mathieson (2000).

${ }^{7}$ Fukuda and Ono (2005) build an open economy model with monopolistic competition among firms that generates high inertia in the currency invoicing of exports. This provides an explanation of the dollar's dominant and stable role in invoicing international trade transactions. Since trade patterns affect the composition of foreign reserves, this theory suggests one explanation for the high persistence of the dollar in reserve holdings.
} 
reserve composition. Not only are these factors highly significant and robust determinants of the currency composition of reserve holdings, but their importance is very stable across time. Dooley, Folkerts-Landau and Garber (2003, 2004) also emphasize the role of trade links and currency pegs as the key reasons behind East Asian and Latin American central banks' unwillingness to follow a pure textbook diversification strategy. They argue that if the dollar peg and export growth are the key objectives of East Asian economies, that should limit diversification away from the US dollar. Our results suggest that even if the East Asian countries increase their trade with the euro zone and issue euro-denominated securities, as long as they peg their currencies against the dollar, it is very unlikely that they will massively diversify away from the dollar.

\subsection{Case study and survey evidence}

Although many central banks do not release data on the actual composition of their reserves, they are becoming increasingly transparent on their general asset management strategies. Recent collections of articles by the Royal Bank of Scotland and the European Central Bank (RBS, 2003, 2005; ECB, 2004) provide interesting information from central bank asset management practitioners as well as survey data on their reserve policies. The main message from these collections is that central banks do follow a portfolio optimization strategy, while also taking into account the unique features of monetary authorities.

The reviews by Reddy (2003) and De León (2003) of the asset management practices of the Indian and the Canadian central banks respectively suggest that these institutions pursue mean-variance portfolio diversification policies in their main international holdings. ${ }^{8}$ This is further emphasized in Naameh's (2003) overview of developing countries. Naameh also presents evidence that constraints associated with trade, debt composition and the currency peg are particularly important for emerging market and developing countries: "A country in the CFA zone may need to service its debt in US dollars, pay for its net imports in Japanese yen and intervene in the foreign exchange market in euros. In such a case, the portfolio will be severely constrained, so the best available assets and their relative weights will not determine its return and risk." Along related lines, Gmuer and Cavegn (2003) rationalize the Swiss

\footnotetext{
${ }^{8}$ Diversification is also stressed by Hansen, Olgaard and Hensen (2003) in their review of the Danish Central bank approach. They write: "The ratio between yield and risk can be improved by spreading the krone duration into additional currencies. ... The smaller the degree of covariation between the interest rates of the currencies in which the reserve is placed, the greater the diversification gain. Distribution on several currencies also spreads the liquidity risk."
} 
central bank's hiring of external portfolio managers by the absence of such constraints. Fisher and Lie (2004) represent the central bank decision problem as an explicit meanvariance optimization exercise (theirs is quite different from ours, in that they assume given returns and optimize over asset classes).

This country-specific case-study evidence is confirmed in the 2003 and 2005 central bank surveys conducted by Pringle and Carver (RBS 2003, 2005). Although these studies should be read cautiously (the questions are quite general, there are selectivity issues; and most central banks with big reserves did not participate), they tend to validate the importance of pegs, trade, external debt and geopolitical factors in reserve composition. There is some indication that central banks are shifting towards euro-denominated securities. ${ }^{9}$ For example, 39 central banks out of the 45 replied that they have increased their exposure to the euro, while only 15 central banks increased exposure to the US dollar and 29 reduced this exposure. In addition most respondents stated that they were considering alternative currencies for further diversifying their risk (such as the Swedish and the Norwegian krona or the Australian and Canadian dollar) which offered higher returns and lower correlation with the other major currencies, while being highly liquid.

\subsection{Key findings on reserve composition}

The main findings on reserve composition that we incorporate in our currency optimization framework are the following:

1. Monetary authorities tend to hold a high share of their reserves in the currency of their main trading partner(s).

2. The currency composition of foreign debt is a significant factor in the allocation of central banks' reserve holdings. Since sovereign and private issuance in euro-denominated securities has increased greatly since 1999, this would imply that central banks will raise the proportion of their reserves in euros to match country assets with liabilities.

3. A central bank that pegs its domestic currency to a given currency tends to hold a larger share of its reserves in that currency. Although the dollar is still the main anchor currency, the importance of the euro is steadily increasing. Currently almost 50 countries

\footnotetext{
${ }^{9}$ Pringle and Carver (2005) thus conclude that "diversification from dollar-denominated to eurodenominated assets appears to be taking place more rapidly than had been anticipated two years ago (in the 2003 survey), although this result may to some extent reflect revaluation changes". See footnote 1 above.
} 
have officially pegged their exchange rate to the euro (ECB 2005). Although pegging to the euro is mainly observed in the new EU member states and EU neighboring regions, countries with sizable reserve holdings outside the European sphere of influence, like Russia and Libya, are using the euro in their basket peg (or basket reference value, like China).

4. Central banks pursue portfolio diversification strategies, but with a high risk aversion and a desire to have liquidity especially during periods of turmoil. The introduction of the euro reduced diversification opportunities, so ceteris paribus one should have expected a fall in the euro share after 1999. But the euro market has become more liquid and deeper, and foreign exchange transaction costs for the euro have fallen.

\section{Methodology}

Following the empirical evidence suggesting that central banks employ (explicitly or implicitly) risk diversification strategies, we propose a dynamic mean-variance framework with constraints and transaction costs. ${ }^{10}$ For each period (year), the central bank maximizes:

$$
\max _{w_{i}, w_{f}} E_{t}\left[R_{t+1}\right]=\sum_{i=1}^{I} w_{i, t} E_{t}\left(r_{i, t+1}\right)+w_{f, t} r_{f, t+1}
$$

Subject to:

$$
\begin{gathered}
W_{t}^{\prime} V_{t+1} W_{t} \leq \sigma^{2} \\
\sum_{i=1}^{I} w_{i, t}+w_{f, t}=1, \forall t \\
w_{i} \geqslant 0 \forall t \text { and } \forall i
\end{gathered}
$$

$E_{t}\left(r_{i, t+1}\right)$ indicates the expected (in period $t$ ) return on currency $i$ in the next period $t+1$, and $r_{f}$ is the return in the risk-free asset. We assume here that currency returns are

\footnotetext{
${ }^{10}$ The inclusion of transaction costs makes the problem dynamic in the sense that initial allocations matter in the optimization since they alter the expected returns vector (see also Codirla, Siourounis and Woo (2005)). Fisher and Lie (2004) implement an analogous but static approach with given (non estimated) returns and variances.
} 
expressed relatively to the the US dollar and thus use the one-year USD interbank rate as the risk-free asset. We consider alternative risk-free assets subsequently. $w_{i, t}$ denotes the share of currency $i$ in the portfolio in year $t . \sigma^{2}$ indicates the desired portfolio variance, $W$ is the vector of portfolio weights (with elements $w_{i, t}$ ) and $V$ is the variance-covariance matrix of (expected) returns. The weights on each currency sum to one. We also require that central banks do not take short positions in any currency. ${ }^{11}$ The problem that the central bank faces is thus to choose a portfolio of currencies that maximizes returns for a given volatility (risk tolerance). There are two challenges in performing this maximization routine, predicting currency returns and projecting the variance-covariance matrix.

\subsection{Expected Currency Returns}

One can decompose the expected returns in currency $i$ in period $t$ as the one-year interest rate yield and the change in the exchange rate. ${ }^{12}$ Denoting the log spot exchange rate as $s$, currency returns can be written:

$$
E_{t}\left(r_{i, t+1}\right)=b_{i, t}+E_{t}\left(s_{i, t+1}-s_{i, t}\right)
$$

where $b_{i, t}$ is the interest rate on currency $i$.

Although interest rates are known at the beginning of each period, future (one-year) exchange rates are notoriously hard to predict (Meese and Rogoff, 1983; Obstfeld and Rogoff, 1995). Although the uncovered interest parity condition (UIP) dictates that currencies of similar risk should have the same returns, a vast literature indicates that the exchange rate, especially over short horizons, follows a random walk and is almost impossible to predict. ${ }^{13}$ The interest rate parity condition appears to hold, but only in the medium and long term (3-5 years).

We will thus present estimates based on four different assumptions on currency returns. First, we assume that the exchange rate follows a random walk. In this scenario the return

\footnotetext{
${ }^{11}$ Relaxing this constraint makes the base currency less important since the investor can borrow (go short) in a low carry currency and invest (go long) in a high carry one and still be consistent with her risk profile.

${ }^{12}$ If central banks issue local currency for intervention purposes, then FX returns are given by the interest rate yield differential between foreign $\left(b_{i, t+1}\right)$ and domestic bills $\left(b_{t}\right)$ plus the expected exchange rate fluctuations. For simplicity we assume that the global investor earns the full interest rate yield $b_{i, t}$ or equivalently that $\left(b_{t}\right)=0$. It can be shown that this assumption does not change our conclusions in any significant way.

${ }^{13}$ See Hau and Rey $(2004,2006)$ and Siourounis (2004) for empirical models linking exchange rates with equity returns and capital flows that beat a random walk for some currency pairs and some horizons.
} 
is just $b_{i, t}$. Second, we assume that central banks have perfect foresight (knowledge) of exchange rate movements. Thus we use actual realized exchange rate changes, which add to the interest rate yield differential. Third, we assume that UIP holds, i.e. currency returns are equalized across currencies. In this scenario the central bank just minimizes the variance of its currency portfolio. Fourth, we continue to assume equal returns across currencies, but we also augment the optimizer with rebalancing costs, which we proxy with extreme bid-ask spreads (calculated over the past year). Transaction costs may significantly reduce returns. They can also affect the direction of reallocation if the market outlook suddenly changes and a shift out of a given position is required.

To address uncertainty further, in all Tables we present results using simulations that allow for error in forecasting currency returns (with each of the four previous methods). Specifically we will assume that the noise follows a Gaussian process with zero mean and the variances of each individual asset variances (the diagonal elements of $V_{t+1}$ ). In all Tables (unless otherwise specified) we simulate 500 portfolios and report the mean of these as the most plausible estimate. ${ }^{14}$

\subsection{Variance-Covariance Matrix}

Another challenge is to project the variance-covariance matrix (VCM) of returns $\left(V_{t+1}\right)$. The forecast of the variance-covariance matrix is at the heart of the mean-variance optimization framework, since the estimated shares appear sensitive to even small changes in the elements of the VCM.

For robustness we follow three different computational methodologies to produce estimates of the VCM: Simple historical; Constant Conditional Correlation multivariate GARCH (CCC-GARCH) (Bollerslev, 1990); and Dynamic Conditional Correlation multivariate GARCH (DCC-GARCH) (Engle, 2002; Engle and Kroner, 2001; Engle and Sheppard, 2001; Cappiello et al., 2003). The difference between simple historical and CCC-GARCH is that the latter allows for time-varying volatility. The difference between CCC-GARCH and DCC-GARCH is that the latter allows for time-varying correlations. For precision we use daily data (from Bloomberg) and estimate the VCM matrix using a four-year window. ${ }^{15}$

\footnotetext{
${ }^{14}$ Results with 100 replications do not depart significantly from those with 500 or 1,000 . We also experiment in some models with 5,000 replications to find quite similar results.

${ }^{15}$ We use 252 trading days per calendar year, which amount to 1008 daily observations per estimation window. In the GARCH estimates we use one lag for both conditional variances and correlations. We note
} 
In all tables (unless otherwise specified) we assume that central banks have a conservative annual risk appetite of $\sigma=3.3 \%$. We can express this as a risk management quantity, the Value at Risk (VaR). If next period's value of the portfolio is $E V_{t+1}=W_{t}^{\prime} R_{t+1}$, then the VaR constraint requires that:

$$
\operatorname{Pr}\left(W_{t}^{\prime} R_{t+1}<-E V_{a}\right)<a
$$

Here $E V_{a}$ is the maximum capital loss tolerated over any year with probability $a$. We set $a=5 \%$ and $E V_{a}=5.4 \%$, which is equivalent to the $3.3 \%$ annual risk set above. ${ }^{16}$

We study the five main international currencies, the US dollar (USD), the Swiss franc (CHF), the Japanese yen (JPY), the British pound sterling (GBP) and the euro (EUR). Before 1999, we replace the euro with the three main EMU currencies, the Deutsche mark (DEM), the French franc (FFR) and the Dutch guilder (NLG). ${ }^{17}$ We carry out the optimization for the five years before, the year of and the five years after the introduction of the euro (the period 1995-2005) and then compare the "optimal" share in the euro currencies in each period, before and after $1999 .^{18}$

\subsection{Transaction Costs (Bid-Ask Spreads)}

We also introduce in the optimizer transaction costs as a further element of realism. A key feature of an international currency is low transaction costs (Niehans, 1971; Portes and Rey, 1998). Transaction costs are also important in the recent microstructure approach to the foreign exchange market (Lyons, 2001). Table 2 presents bid-ask spreads from Bloomberg of the main international currencies against the US dollar from December 1995 until October

that GARCH is used as a filter that aims to capture structural relationships between underlying returns series and estimate the correct conditional variance and correlation means. We acknowledge, however, that one could generate 1 year ahead VCM forecasts by iterating forward the estimated GARCH equations (for DCC-GARCH, see Engle and Sheppard, 2001; for an application of DCC-GARCH to bond returns see Cappiello et al., 2003). Given the mean-reverting nature of GARCH and the one year forecast horizon, 252 forward iterations result in estimates very close to the long-run conditional variance and correlation means used here.

${ }^{16}$ We explore the sensitivity of the optimal allocations to this risk tolerance in Section 4.5.

${ }^{17}$ At birth of the EUR the shares of DEM, FRF and NLG were respectively $34.38 \%, 17.47 \%$ and $10.53 \%$. Source: European Central Bank.

${ }^{18}$ At 31 December 1998, we include just the DEM as the closest proxy for the euro. We report results based on a yearly horizon since central banks report yearly financial statements. We also experiment with a two- and three-year horizon finding similar results. In the previous version of the paper we also added gold in the optimization to find similar results. Here we ignore gold, however, since it is part of a larger problem for central banks, that of cross-asset allocation, and because gold holdings in developing countries (that are the big foreign exchange reserve holders) are minimal. 
2005. Bid-ask spreads are one measure of liquidity on the foreign exchange market. The Table presents the mean bid-ask spreads based on daily data over the last year, as well as the maximum value over the previous year. ${ }^{19}$ In an early assessment of the effect of the euro on the foreign exchange markets, Hau et al. (2002a, 2002b) found that bid-ask spreads (as well as turnover) for most bilateral euro markets during 1999 were systematically higher than they were during 1998 for bilateral markets for the German mark. Detken and Hartmann (2002) found similar results (but of lower magnitude) in a larger sample.

The data are partly in line with these early findings. Mean spreads in the USD/DEM exchange rate were $0.04 \%$ in 1998 , while mean spreads in the EUR/USD market were somewhat higher at $0.05 \%$ and $0.07 \%$ during the first two years of the euro. But this was temporary. Mean spreads in the euro market have fallen to minimal levels in the past two years (at $0.01 \%$ ). Although spreads vis-a-vis the dollar have fallen in all major currency markets, the euro and the pound sterling markets are consistently the most efficient during the past two years. Still, mean spreads might not reflect accurately the transactions costs of rebalancing, since central banks often need to intervene in the market in periods of turmoil. Thus Table 2 also reports the maximum bid-ask spread over the previous year. ${ }^{20}$ The data clearly indicate that the euro has brought sizable gains in this regard, since extreme spreads have narrowed drastically. For example, during the four years before the introduction of the euro, the maximum spread in the Deutsche mark, the French franc and the Dutch guilder were $0.68 \%, 0.44 \%$ and $0.53 \%$ respectively. ${ }^{21}$ Yet since the beginning of 2001 , the maximum bidask spread in the EUR/USD market was 0.11\%. Thus foreign central banks now have a much more attractive alternative, since even in periods of liquidity crunch the euro foreign exchange markets seem highly liquid, with quite low transaction costs. ${ }^{22}$ In addition other

\footnotetext{
${ }^{19}$ Mean spreads are calculated as the mean bid-ask spreads for every year prior to the optimization and then expressed as a percentage of the mid-price at the time of the optimization.

${ }^{20}$ Extreme spreads are calculated as the maximum value of the bid-ask spread in the year prior to the optimization and then expressed as a percentage of the mid-price at the time of the optimization.

${ }^{21}$ On 2 October 2000, sterling experienced a very large shock linked to the overall negative environment of global asset markets. In 2003, the Swiss franc had a day of very wide spreads when the announcement from the central bank regarding the inflation and growth outlook was a big surprise for market participants. We exclude these events from our analysis. Our results do not depart in any significant way from the those reported here.

${ }^{22}$ Our analysis just compares bid-ask spreads in the foreign exchange markets against the dollar. Clearly to get a full picture of the effect of the euro in lowering transaction costs, one needs to examine turnover and spreads in other markets as well. For example, the Brazilian real/USD market is more liquid than the Brazilian real/EUR market, and this holds for most such pairs. Thus the dollar has so far maintained its role as the dominant vehicle currency: in the April 2004 BIS survey of foreign exchange markets, the dollar was involved in $88.7 \%$ of reported transactions (90.3\% in 2001), the euro in $37.2 \%$, the yen in $20.3 \%$, the pound sterling in $16.9 \%$, and the Swiss franc in $6.1 \%$ (Bank for International Settlements, 2004).
} 
major currencies have enhanced their liquidity, and spreads have also fallen, as for the two Scandinavian currencies and the Canadian dollar. This makes diversifying away from the US dollar particularly attractive, since these currencies are not so correlated with the dollar and are now relatively cheap to trade. ${ }^{23}$

\section{Results for the representative central bank}

\subsection{Random walk of the exchange rate}

We start by estimating optimal currency weights assuming that the exchange rate follows a random walk. Thus we assume that in each year the expected currency appreciation/depreciation is zero, so that central banks just realize the one-year carry (interest rate). Panel A of Appendix Table A reports the one-year money-market rate (inter-bank rate) at the end of each year for the main currencies we consider in our analysis. The pound sterling usually has the highest yield, while the yen and the Swiss franc have the lowest yields. Although central banks most likely do not perform "carry" strategies, since uncovered interest parity dictates that the exchange rate should move to compensate for these differences, it is useful to investigate the allocations that the optimizer yields.

Table 3 presents the results under the three different projection methods of the variancecovariance matrix of returns. Reflecting the big changes from year to year in short-term interest rates, the optimizer yields unstable estimates. For example, the optimal allocation to the dollar falls significantly in 2001-2003, when the Fed lowered interest rates to help the economy recover from the recession. The recent tightening of US monetary policy resulted in an immediate increase in the optimal dollar allocation. Reflecting their low interest rates, the optimizer assigns an allocation close to zero for the Swiss franc and the yen. But it also gives a very low share for the euro. In fact, only USD and GBP attract significant allocations.

The large share for the dollar reflects its status as the risk-free asset and the interdiction of short sales. Since currency markets are highly positively correlated, the short-sale constraint is important: it stops the investor from utilizing this high correlation by going short and thus reversing the positive correlation to a negative one, in order to provide diversification. Hence

\footnotetext{
${ }^{23}$ Bid-ask spreads are only one indicator of market liquidity. We use them because they can easily be integrated into the mean-variance framework.
} 
the only way central banks can achieve a low risk portfolio here is to hold a high proportion in the risk-free asset. Moreover, some other currencies have lower returns (notably the JPY), so the optimizer assigns large allocations to the dollar. But GBP gets a high share because of high interest rates. This first exercise illustrates some of the difficulties in applying the mean-variance framework to our problem.

\subsection{Perfect foresight}

Since their control over monetary policy should give central banks superior information about exchange rate movements, one could ask what the optimal portfolio allocation would be assuming perfect foresight regarding currency returns. Realized currency returns (the percentage change in the nominal exchange rate in equation (2)) are reported in Panel B of Appendix Table A. We thus maximize (1) using realized returns, which equal the one year inter-bank rate plus the realized one-year exchange rate movement (sum of Panel A and Panel B of Appendix Table A). These changes are based on a buy-hold strategy (buy on 1 January of each year and sell on 31 December of the same year). Reflecting the high volatility in exchange rate movements, the optimal weights are again unstable, with no clear patterns. For example, assuming (almost) perfect foresight at the introduction of the euro in 1999 implies that central banks knew that the euro would depreciate substantially (yielding negative returns overall). Not surprisingly, then, the optimizer allocates a zero share to the euro. Again, the short-sale constraint treats the dollar favorably as the risk-free (reference) currency that gets a high allocation. The euro does well when it is appreciating but gets a negligible allocation when it is depreciating.

\subsection{Minimum variance}

The results given in Table 3 and Table 4 illustrate the big challenges in applying the meanvariance framework to a portfolio allocation among currencies. On the one hand, if one assumes a random walk of the exchange rate, then the optimal allocation focuses on the currency which has the highest yield (carry). Not only does this go against the interest parity condition, but it is very unlikely that a central bank will bet on the carry, since this would imply continuous rebalancing, with possibly destabilizing consequences in the foreign exchange market. On the other hand, if one makes the unrealistic assumption of perfect foresight, then naturally it does not make much sense for an investor to allocate much to an 
asset with negative returns (unless she needs to be invested in that asset with the associated risk).

We therefore ask what central banks would do if they just wanted to invest in the minimum variance portfolio, since currency returns are almost unpredictable. Table 5 reports the minimum variance portfolio allocations. These are obtained by simply minimizing the variance-covariance matrix of the risky assets. Since all assets are expressed relatively to the dollar, the optimization does not include the risk-free asset (the USD). Although we therefore cannot examine how the optimal allocation to the dollar changes relatively to the other main currencies, it is useful to examine the optimal allocation to the euro as compared with GBP, JPY and CHF. The share of EUR is high in 1999-2000, but then falls sharply. In contrast the optimal allocations to sterling and the yen rise notably after 1999-2000. The Swiss franc does not appear in any optimal portfolio, primarily due to its high correlation with the euro.

\subsection{Interest parity with transaction rebalancing costs}

Since the five main international currencies have comparable risk characteristics, interest parity dictates that the expected currency returns (interest plus expected exchange rate movement) should be equalized. Although a vast literature suggests that UIP does not hold (see Sarno and Taylor, 2004), we follow others in believing that this is the most plausible approach for central banks. Central banks typically do not speculate on short-term fluctuations among the main international currencies and follow a medium-term portfolio strategy (Pringle and Carver, 2005). If we assume that UIP holds, we implicitly assume that all currency pairs have the same total expected return as the risk-free asset. In the presence of transaction costs, the returns of the risky assets become unattractive since they are lower compared to the return of the risk-free asset, but they come at a positive risk. Nevertheless, central banks need to have positive allocations in more than one currency to maintain liquidity, debt service and trade payments. ${ }^{24}$ In addition, recall that with the simulation we perform, we explicitly assume that the UIP might not hold exactly. In this case, although the risky assets are (by default) unattractive, central banks still want to include them in their portfolio. Within the mean-variance framework the only way we can get positive allocations in the risky assets, even if they offer returns inferior to the risk-free asset, is to

\footnotetext{
${ }^{24}$ We explicitly assess some of these needs in the following section.
} 
take risk. We continue to use a conservative annual portfolio volatility of $3.3 \%$. In Table 6 we present mean-variance portfolio allocations for a global investor in the currency market using extreme bid-ask spreads in the previous year to represent rebalancing costs. ${ }^{25}$ In this set of estimates, the optimal weight of the dollar falls in 1999 but then recovers and stabilizes around 60\%. The euro allocation falls after 1999. The yen and Swiss franc allocations are relatively stable and show advances relative to sterling. ${ }^{26}$ Thus this most realistic scenario yields an allocation to the dollar that is close to the observed share, while (depending on monetary policy changes across Japan, Europe, Switzerland and the United Kingdom) the optimal shares in the other currencies are on average the same.

To summarize so far: Adding transaction costs makes returns unequal and thus gives more content to the exercise. The 'optimal' share of the dollar is close to what we observe, that of the euro, at a level similar to the Swiss franc, the yen and the sterling, is less than half what we observe in the data. We interpret that as preliminary evidence that the euro is becoming an international currency, insofar as actual shares of the euro substantially exceed those that portfolio optimization would imply. But for the euro to challenge the dollar, central banks would have to treat the euro as the reference (risk-free) currency. There would also be some shift out of the dollar if central banks were to allow selling currencies short, which would increase allocations to risky assets. This is a rather different perspective on currency competition than one finds in the existing literature.

\subsection{Alternative assumptions and robustness tests}

\subsubsection{Risk profile}

All our optimizations so far have assumed a desired annual portfolio volatility of $3.3 \%$. Table 7 investigates how the portfolio allocations change if we assume higher or lower desired portfolio volatility. We carry out the exercise assuming UIP and transaction costs and use

\footnotetext{
${ }^{25}$ In a previous version of the paper we presented results also using mean spreads. We believe, however, that extreme spreads more accurately capture central banks' needs. The results with mean spreads are available upon request. To capture transactions costs fully, we should include the spreads on purchases and sales of securities such as government bonds (Portes and Rey, 1998, stress the importance of these transaction costs). This we leave to future research.

${ }^{26}$ Note that bid-ask spreads are an increasing function of currency volatility (this emerges from study of the foreign exchange market microstructure and from empirical evidence such as in Hartmann, 1998). Therefore in this exercise we are over-penalizing variance.
} 
DCC-GARCH for the VCM, so the results here are directly comparable to those of Panel $\mathrm{C}$ in Table 6. As we should expect, we observe that greater risk aversion (annual standard deviation of $2.3 \%$ ) leads to a higher allocation to the dollar, whereas lower risk aversion gives higher allocations to all the alternative currencies. The effect of varying risk aversion is shown graphically in Figure 3, where we see the optimal portfolio allocations in October 2005 as a function of different levels of this parameter. Note that as we increase risk tolerance the optimizer assigns larger weight mainly to the pound sterling, which has the highest returns.

\subsubsection{Fat tails}

All our calculations so far are generated by shocking the expected returns vector with an iid Gaussian error, which has zero mean and standard deviation equal to that of the corresponding currency. A robustness check is provided by using a distribution of currency returns with fat tails (assuming a different distribution, like a power law, would make our mean-variance framework meaningless). We see the results in Table 8. Again, we assume UIP and transactions costs and use DCC-GARCH, so the relevant comparison is with Panel $\mathrm{C}$ of Table 6 . The differences are minimal.

\subsubsection{The importance of the reference currency}

Our discussion so far has already suggested that the role of the dollar as the risk-free currency in our optimizations may be a key to the results we obtain, which give it a high share in the calculated optimal portfolios. Since returns do not vary greatly, there is a strong "bias" towards holding the asset with zero variance. These shares are not far from those observed in the data. One interpretation is that the dollar's high share reflects its status as the "safe haven" currency. Another is that central banks do in fact use the dollar as the reference currency for expressing returns on alternative assets. Our preferred interpretation, however, is that taking the dollar as the risk-free asset corresponds to the case in which the domestic currency is pegged to the dollar, so there is zero volatility with respect to the dollar. This is consistent, for example, with the results of Dellas and Yoo (1991) for Korea. As we shall see below, when the reference currency is the domestic currency, the optimal portfolio allocations change substantially when there is a change in the exchange-rate regime (e.g., moving off a peg to the dollar).

One way of investigating this effect is to try alternative reference currencies in our calcu- 
lations for the representative central bank. We see the results in Table 9, where we re-base all currencies in the SDR, JPY and EUR. We continue to assume UIP but no transactions costs. We use DCC-GARCH for the VCM, so the results are in principle comparable with Panel $\mathrm{C}$ of Table 6 (the only difference being the inclusion of bid-ask spreads). The allocations confirm the importance of the reference currency in all three cases. Before 1999-2000 we get the same result as before: the risk-free asset dominates all other allocations. After 2000, however, and only when the EUR is used as the base currency, we see a sizable reduction in its allocation and at the same time a significant rise in all other allocations and particularly the Swiss franc. This is mainly due to the fact that after 2000, appreciations of the EUR relative to the USD were followed by appreciations of the CHF relative to the USD of about the same magnitude. This resulted a quite stable EUR/CHF cross that is reflected in the extremely low estimated volatility and correlation in the empirical VCM. This observation is true for the other crosses as well but to a lesser extent. Market participants have repeatedly signalled the notable reduction of the observed as well as the implied volatility in the FX market. This is the first preliminary evidence within a mean-variance framework of the EUR effect in the observed volatility of the FX market. We also believe that the importance of the reference currency is strong evidence for the importance of currency peg arrangements in determining the composition of reserves. We offer additional evidence for this claim in Section 5.3.

\section{Simulated results for the BRICs with constraints}

As we have seen, a central bank wishes to hold a significant share of its reserves in the currencies of its country's external debt and in the currencies of its main trading partners. These two factors help to explain the significant share of the dollar since the 1970s, when the American economy was by far the largest market for developing countries' exports, and the dollar was the main currency of security issuance. But during the last few years, issuance in euro-denominated securities has increased substantially, even from firms and governments outside the euro zone (ECB 2005). In addition, the euro zone is of comparable weight to the US in international trade. To assess the impact of the currency composition of foreign debt and the direction of trade we augment the currency optimizer with constraints reflecting the debt and trade desiderata.

We cannot do this for the (aggregate) "representative central bank", nor would we learn 
much from studying the reserve-holding behavior of the major developed countries, because they cannot hold their own currencies as foreign exchange reserves. We therefore focus on four large emerging market countries: Brazil, Russia, India, and China, all of which have been accumulating foreign assets rapidly. Not only are these countries the largest emerging economies in terms of both population and GDP, but they are among the largest foreign exchange reserve holders. Indeed China has the highest reserves in the world, on a par with Japan. Following the recent increase in oil prices and exports, Russia is now the sixth largest reserve holding country. India is the seventh, while Brazil has the second highest reserves (after Mexico) in the Western hemisphere. The BRICs also give us a geographical spread.

We believe that the optimization story is very appealing for these as well as other countries with large reserve holdings, while it might not be a very suitable representation of the reserve composition decision of central banks with relatively low levels of foreign assets. That is because those central banks might need to hold almost all their reserves in dollars, since the dollar's status as the vehicle currency means that market interventions usually take place in the USD market. For countries with such large holdings as the BRICs, however, maximizing returns should be a key objective of reserve management.

\subsection{Currency composition of external debt}

We begin by incorporating into the optimizer constraints requiring that each of the four countries has to hold a specified share of its reserves in the currency of its external debt. In Table 10 we report optimal allocations when the central bank wants to hold reserves in the currencies of the country's external debt at levels at least equal to $50 \%$ of the share of the debt in each currency. For example, in 1997 Russia had approximately 65\% of its external debt issued in USD and 29\% issued in DEM (see Appendix Table B for the actual shares). For that year, we thus impose as a constraint that the Russian central bank would want to hold at least $32.5 \%$ of its reserves in dollars and $14.5 \%$ of its reserves in Deutsche marks. The $50 \%$ thresholds are of course ad hoc. ${ }^{27}$ Since we impose the same constraint across all major currencies, however, we can still make inferences over time, assessing how the replacement of the French franc and the Deutsche mark by the euro changed the optimal composition of international reserve holdings. Data for the currency composition of external debt come from the latest update of the World Bank's Global Development Finance Database. Our

\footnotetext{
${ }^{27}$ We also experiment with other thresholds, imposing for example that each of the four central banks holds at least either $75 \%$ or $25 \%$.of the share of the debt in each currency. The results are quite similar.
} 
preferred comparisons are between the pre-1999 years and 2002 and 2003, since there are data limitations regarding the foreign debt statistics for the 1999-2001 period.

Table 10 presents the results of the constrained optimization problem. We assume constant currency returns (UIP holds) and proxy the rebalancing costs with maximum bid-ask spreads in the previous year. For brevity we only report estimates in which we project the variance-covariance matrix with DCC-GARCH (results are similar when we either employ historical estimation or with CCC-GARCH). So the procedure is similar to that of Panel C in Table 6. First, the results indicate that the optimal share of the euro for Brazil and Russia is significantly higher than for the representative central bank in Table 6. Reflecting the relatively low issuance of euro-denominated debt in China and India, the optimizer assigns lower weights in the euro for the two Asian countries. Second, the role of the dollar remains significant, with relatively stable shares in all four countries in the range of $50 \%$ to $60 \%$.

But data limitations make the results in Table 10 tentative and at best indicative. The coverage of the data ends at 2003, which is when foreign governments and corporations outside Europe started issuing euro-denominated securities at an increasing pace (ECB 2005). In addition, the maturity of the debt is also a key factor for central banks, and it probably would be desirable to use the currency composition of short-term debt. ${ }^{28}$

\subsection{Direction of international trade}

It is also of great interest to examine how the pattern of trade influences optimal reserve allocation. Not only has the direction of trade been found to be a significant determinant of reserve composition in the empirical studies, but trade shares are relatively stable over time. In addition, international trade patterns also capture the other two main factors that central banks take into account, the composition of debt and the composition of the basket peg. On the former, recent evidence shows that countries issue and trade securities with the same countries that they trade goods (e.g. Aviat and Courdacier, 2004; Rose and Spiegel, 2004; Lane, 2005). Thus the trade statistics also capture (part of) the currency of external debt issuance. On the latter, Shioji (2005) simulates a multi-country dynamic open economy model and shows that the currency invoicing of trade has a direct effect on the optimal currency composition of the basket peg.

\footnotetext{
${ }^{28}$ Unfortunately, the Global Development Finance Database does not report the currency composition of short-term debt. But since most emerging economies borrow over short maturities, using the currency shares of both short and long-term debt obligations is still quite useful.
} 
We proceed by incorporating the desire of the BRIC central banks to manage their reserves partly depending on the trade share (imports plus exports as a percentage of total trade with the world) with each of the four developed countries. ${ }^{29}$ Data come from the IMF's Direction of Trade Database and also cover 2004. For comparability with the external debt estimates we also report estimates with a 50\% threshold. ${ }^{30}$ For example, in 2004 the share of Brazilian trade with the US and the euro zone was almost the same at 20\% (see Appendix Table $\mathrm{C}$ for the actual shares). We thus impose that the Brazilian central bank wants to hold at least $10 \%$ of its reserves in dollars and at least $10 \%$ in euros. In 2004 the euro zone was the main trading partner for Russia, accounting for more than $45 \%$ of Russian exports and imports. It was also the main trading partner of India and Brazil, although the actual shares of trade were not significantly higher than that with the US. China on the other hand had approximately the same trade shares with the euro zone, the US, and Japan.

The constrained optimization results assuming that expected currency returns are equalized are given in Table 11. For brevity we report estimates based on a DCC-GARCH filtering of the VCM and also incorporate transaction costs with extreme bid-ask spreads in the previous year. These are also our preferred estimates, since we are capturing both liquidity needs and trade invoicing, which also proxies for foreign debt issuance.

First, reflecting the increasing weight of the euro zone in international trade, the optimal allocation to euros increases significantly, notably in Russia (around 25\%) and Brazil (around 15\%). For China and India, the share is somewhat over 10\%. These are higher than in Table 6. Still, in all countries the optimal weights of the euro are smaller than the observed holdings. We again interpret this as an indicator of the rapid internationalization of the euro, 'punching above its weight'. Second, the allocation in the dollar continues to be very close to the observed (reported) shares.

\footnotetext{
${ }^{29}$ We also experiment with exports and imports separately and find similar results.

${ }^{30} \mathrm{It}$ would have been preferable to use data on trade invoicing rather than the direction, since foreign reserves are used for international payments. For example Shioji (2005) makes a connection between invoicing rather than the direction of trade and the optimal currency peg. But lack of data precludes this. ECB (2005) and Kamps (2005) provide tentative evidence indicating an increased role of the euro as an invoicing currency in international trade, using an unbalanced panel of more than thirty countries.
} 


\subsection{The minimum variance portfolio with all returns expressed relative to the domestic currency}

Expressing returns in domestic currency units helps to capture any de jure or de facto currency pegs, since then central banks would intervene in the foreign exchange markets in the currency of the peg. We thereby incorporate the third factor that has been found to be a significant determinant of reserve composition. Moreover, it resolves the 'technical' problem we found above, in that we could not include the dollar in the minimum variance problem since it was the base currency. We report results using the composition of trade constraint.

The results in Table 12 are highly unstable. And since at least in some time periods, central banks try to minimize the volatility of their exchange rate against the dollar, the share of the dollar is typically very high. The euro emerges as a distant second. We note that a mean-variance approach would not apply in this context: First, we cannot treat the domestic currency as the riskless asset, since this is the liability of the central banks. Second, given the currency peg that some countries follow explicitly or implicitly, they minimize volatility with the peg currency (USD here) rather than maximizing returns. In this framework, China's tight peg to the dollar naturally gives it the dominant role in China's reserves. In years when pegs collapsed (Russia 1998, Brazil 1999), the dollar no longer gives minimum variance, and the euro's share increases substantially. That suggests it is indeed the 'alternative' international currency. Third, for countries like Russia and Brazil where the minimum variance is much higher than our $3.3 \%$ limit, we would need to assume exotic risk preferences to apply the mean-variance framework. And given the relatively high domestic interest rates, mean-variance optimization would give $100 \%$ in the risk-free asset - not a very useful result from the standpoint of this paper.

\section{Conclusion}

Foreign exchange reserves have grown rapidly in recent years, and there is as yet no sign that the rate of accumulation will fall. Currently two-thirds of global international reserves are held in US dollar assets. The reserve currency status of the dollar confers an "exorbitant privilege" on the United States (Gourinchas and Rey, 2005b), which can run large and prolonged current account deficits, financing them in its own currency. But academics and money managers encourage emerging market countries' central banks to diversify their assets, 
switching away from the dollar. Recent developments in international financial markets add pressure on the dollar. First, the emergence of the euro offers a serious alternative placement for foreign assets. Moreover, after a brief initial period, transaction costs in the euro currency markets have fallen drastically. Second, several other industrial countries' currencies have also enhanced their liquidity and thus also offer attractive alternative assets for further diversification. Portfolio rebalancing away from the dollar would have immediate implications for the US and the global economy.

Our main methodological contribution is to assess reserve holdings in a dynamic meanvariance optimization framework augmented by transactions costs and with constraints reflecting central banks' special needs. The starting point of our approach is to consider a representative central bank. We make various assumptions about expected currency returns and the structure of the variance-covariance matrix to estimate what a currency optimizer implies for the composition of foreign reserves. Then we incorporate transaction costs in the optimization framework. Since central banks need to provide liquidity in abnormal market times, we use extreme bid-ask spreads to measure rebalancing costs. Finally, turning to individual countries, we can bring into the optimization framework the needs of central banks to hold a sizable portion of their holdings in the currencies of their external debt, the currencies of their main trading partners and the anchor currency of the peg. We performed simulations for four large emerging market countries, Brazil, Russia, India, and China. Although these constraints are ad hoc, we are able to assess the impact over time of the introduction of the euro. The results suggest that since an increasing number of countries issue eurodenominated securities in the international markets and the euro zone is the main trading partner of many developing countries, the optimal share in the euro has increased significantly in recent years. Quantitatively the most important factor, however, appears to be the reference currency to which countries decide to peg their own currencies.

We find that the mean-variance framework with the dollar as the reference (risk-free) asset, together with the interdiction of short-selling and the observed high positive correlations of foreign exchange markets, explains rather well the large shares of the dollar in central banks' portfolios. The pound sterling typically shows a high "optimal" share, whereas those of the yen and the Swiss franc are very low; these calculated shares reflect well the relative returns and variances. Moreover, we find that the actually observed euro allocations are substantially greater than emerge from the optimizations. This we take to mean that the euro has in fact quickly gained status as the 'alternative' international currency. Our results 
suggest, however, that a substantial increase in the euro's share of central bank reserves would require

- that more countries include the euro in their currency pegs (de facto or de jure) - the composition of debt and trade have smaller effects than the choice of reference currency

- that the scope for active central bank management of their portfolios widen by permitting them to take short positions (this becomes increasingly important with the observed trend to increased co-movement of the major currencies)

Recent evidence of moves in the first direction comes from Russia and Eastern Europe, whereas there is some suggestion of movement in the second direction from Japan, Singapore, and perhaps China.

We believe that starting with a theoretically grounded, simple mean-variance framework and properly modifying it to incorporate the specific needs of monetary authorities can bring new insights about the prospects of adjustment. Evidence suggests that an increasing number of central banks pursue similar optimization strategies, consulting or even hiring money managers to assist them. Besides rebalancing the currency composition of foreign reserves, there is currently increasing pressure on central banks to invest in higher return assets, such as mortgage and asset-backed securities, highly rated corporate bonds and even equity. It would be thus very interesting to extend our framework allowing for currency returns in the money markets as well as government bonds, commercial paper and equity of each of the main industrial countries. 


\section{References}

[1] Alogoskoufis, George and Portes, Richard (1991)."International Costs and Benefits from EMU", in The Economics of EMU, European Economy Special Issue No 1, 1991, pp. 231-245.

[2] Alogoskoufis, George and Portes, Richard (1992). "European Monetary Union and International Currencies in a Tripolar World." in Matthew Canzoneri, Vittorio Grilli and Paul Masson (eds), Establishing a Central Bank: Issues in Europe and Lessons from the U.S., Cambridge: Cambridge University Press.

[3] Alogoskoufis, George and Portes, Richard (1997). "The Euro, the Dollar, and the International Monetary System", in P. Masson, T. Krueger and B. Turtelboom, (eds), EMU and the International Monetary System. International Monetary Fund, Washington DC.

[4] Aviat, Antonin and Coeurdacier, Nicolas (2004). "The Geography of Trade in Goods and Assets." DELTA (Paris, France) Working paper 2004-10, May 2004, forthcoming in the Journal of International Economics.

[5] Bank for International Settlements (2004). Triennial Central Bank Survey: Foreign Exchange and Derivative Market Activity in 2004, Bank for International Settlements, Basel.

[6] Bergsten, Fred C. (1997). "The Dollar and the Euro." Foreign Affairs, July/August 1997, pp. 83-95.

[7] Biais, Bruno; Declerc, Fany; Dow, James; Portes, Richard, and von Thadden, Ernst-Ludwig (2006). European Corporate Bond Markets: transparency, liquidity, efficiency, CEPR, London, UK.

[8] Blanchard, Olivier, Giavazzi, Francesco and Sa, Filipa (2005). "International Investors, the U.S. Current Account, and the Dollar", Brookings Papers on Economic Activity, November 2005, 1, pp. 1-65.

[9] Bollesrslev, Tim (1990). "Modelling the Coherence in Short-run Nominal Exchange Rates: A Multivariate Generalized ARCH Approach." Review of Economic and Statistics, 72(2), pp. 498-505. 
[10] Cappiello, Lorenzo; Engle, Robert F. and Sheppard, Kevin. (2003) "Asymmetric Dynamics in the Correlations of Global Equity and Bond Returns" ECB Working paper 204, January 2003.

[11] Chinn, Menzie (1999). "Memo on the Determinants of Central Bank Euro Holdings." mimeo University of California-Santa Cruz.

[12] Chinn, Menzie, and Frankel, Jeffrey (2005). "Will the Euro Eventually Surpass the Dollar as Leading International Reserve Currency?", forthcoming in G7 Current Account Imbalances: Sustainability and Adjustment, Richard Clarida (ed.), The University of Chicago Press, Chicago, ILL.

[13] Codirla, Corvin, Siourounis Gregorios, and Woo, David (2005). "The Barclays Capital FX Optimiser: A User's Manual", Global FX Strategy, Barclays Capital, London, United Kingdom.

[14] Dellas, Harris and Yoo, Chin Bang. (1991). "Reserve Currency Preferences for Central Banks: The Case of Korea." Journal of International Money and Finance, 10(1), pp. 406-419.

[15] De Leon, Jacobo (2003). "How the Bank of Canada Manages Reserves." in How Countries Manage Reserve Assets. Robert Pringle and Nick Carver (Eds.), Central Banking Publications, London, United Kingdom.

[16] Detken, Carsten, and Hartmann, Philipp (2000). The Euro and International Capital Markets", April 2000, International Finance, 3 (1), pp. 53-94.

[17] Detken, Carsten, and Hartmann, Philipp (2002). "Features of the Euro's Role in International Financial Markets." Economic Policy, Fall 2002, 35(2), pp. 555-597.

[18] Dooley, Michael and Garber, Peter (2005). "Is it 1958 or 1968? Three Notes on the Longevity of the Revived Bretton Woods System." Brookings Papers on Economic Activity, November 2005, 1, pp. 147-209.

[19] Dooley, Michael P., Folkerts-Landau, David and Garber, Peter M. (2003). "An Essay on the Revived Bretton Woods System." National Bureau of Economic Research (Cambridge, MA), Working Paper No. 9971, September 2003. 
[20] Dooley, Michael P., Folkerts-Landau, David and Garber, Peter M. (2004). "Interest Rates, Exchange Rates and International Adjustment." National Bureau of Economic Research (Cambridge, MA), Working Paper No. 10727, September 2004.

[21] Dooley, Michael P., Folkerts-Landau, David and Garber, Peter M. (2005). "Interest Rates, Exchange Rates and International Adjustment." National Bureau of Economic Research (Cambridge, MA), Working Paper No. 11711, November 2005.

[22] Dooley, Michael P., Lizondo, Saul and Mathieson, Donald (1989). "The Currency Composition of Foreign Exchange Reserves." International Monetary Fund Staff Papers, June 1989, 36(2), pp. 385-434.

[23] Dunne, Peter, Moore, Michael, and Portes, Richard (2006). European Government Bond Markets: Transparency, Liquidity, Efficiency, CEPR, London, UK.

[24] Eichengreen, Barry (1998). "The Euro as a Reserve Currency." Journal of the Japanese and International Economies, December 1998, 12(4), pp. 483-506.

[25] Eichengreen, Barry (2005). "Sterling's Past, Dollar's Future: Historical Perspectives on Reserve Currency Competition." National Bureau of Economic Research (Cambridge, MA) Working Paper No. 11336, May 2005.

[26] Eichengreen, Barry, and Frankel, Jeffrey (1996). "The SDR, Reserve Currencies, and the Future of the International Monetary System," in The Future of the SDR in Light of Changes in the International Financial System, Michael Mussa, James Boughton, and Peter Isard (eds.), International Monetary Fund, 1996.

[27] Eichengreen, Barry, and Mathieson, Donald (2000). "The Currency Composition of Foreign Exchange Reserves: Retrospect and Prospect." International Monetary Fund (Washington, D.C.) Working Paper 131, July 2000.

[28] Engle, Robert (2002). "Dynamic Conditional Correlation - A Simple Class of Multivariate GARCH Models." Journal of Business and Economic Statistics, July 2002, 20(3), pp. 339-350.

[29] Engle, Robert and Kroner, Kenneth (1995). "Multivariate Simultaneous GARCH." Econometric Theory, 11(1), pp. 122-150. 
[30] Engle, Robert and Sheppard, Kevin (2001). "Theoretical and Empirical Properties of Dynamic Conditional Correlation Multivariate GARCH." National Bureau of Economic Research (Cambridge, MA) Working Paper No. 8554, October 2001.

[31] European Central Bank (2004). Risk Management for Central Bank Foreign Reserves. Carlos Bernadell, Pierre Cardon, Joachim Coche, Francis X. Diebold and Simone Manganelli (Eds.) Frankfurt, Germany.

[32] European Central Bank (2005). Review of the International Role of the Euro. December 2005, Frankfurt, Germany.

[33] European Central Bank (2006). The Accumulation of Foreign Reserves. ECB Occasional Paper 43, February 2006, Frankfurt, Germany.

[34] Feldstein, Martin (1997). "The Political Economy of The European Economic and Monetary Union: Political Sources of an Economic Liability." Journal of Economic Perspectives, Fall 1997, $11(4)$, pp. 23-42.

[35] Fisher, Stephen J. and Lie, Min C. (2004). "Asset Allocation for Central Banks: Optimally Combining Liquidity, Duration, Currency and Non-Government Risk." in Risk Management for Central Bank Foreign Reserves. Carlos Bernadell, Pierre Cardon, Joachim Coche, Francis X. Diebold and Simone Manganelli (Eds.) Frankfurt, Germany.

[36] Frankel, Jeffrey (1995). "Still the Lingua Franca: The Exaggerated Death of the Dollar," Foreign Affairs, July/August 1995, 74(4), pp. 9-16.

[37] Fukuda, Shin-ichi and Ono, Masanori (2005). "On the Determinants of Export Prices: History vs. Expectations", mimeo University of Tokyo and Fukushima University.

[38] Gmuer, Enrich and Cavegn, Gion (2003). "A view from the Swiss National Bank." in How Countries Manage Reserve Assets. Robert Pringle and Nick Carver (Eds.), Central Banking Publications, London, United Kingdom.

[39] Goldman Sachs (2003). "Dreaming with BRICs," Global Economic Paper 99.

[40] Goldman Sachs (2005). "How Solid are the BRICs?" Global Economic Paper 134. 
[41] Gourinchas, Pierre-Olivier and Rey, Hélène (2005a). "International Financial Adjustment." Centre for Economic Policy Research Discussion Paper 4923, February 2005.

[42] Gourinchas, Pierre-Olivier and Rey, Hélène (2005b). "From World Banker to World Venture Capitalist: US External Adjustment and the Exorbitant Privilege." Centre for Economic Policy Research Discussion Paper 5220, August 2005. Forthcoming in G7 Current Account Imbalances: Sustainability and Adjustment, Richard Clarida (ed.), The University of Chicago Press, Chicago, IL.

[43] Greenspan, Alan (2004). Remarks by Chairman Alan Greenspan at the European Banking Congress 2004, Frankfurt, Germany November 19, 2004.

[44] Hansen, Ib; Olgaard, Christian and Jensen, Peter Kaer (2003). "Risk Management of Currency Reserves." in How Countries Manage Reserve Assets. Robert Pringle and Nick Carver (Eds.), Central Banking Publications, London, United Kingdom.

[45] Hartmann, Philipp (1998a). Currency Competition and Foreign Exchange Markets. Cambridge University Press, Cambridge, United Kingdom.

[46] Hartmann, Philipp (1998b). "The Currency Denomination of World Trade after European Monetary Union." Journal of the Japanese and International Economies, 12(4), pp. 424-454.

[47] Hau, Harald, Killeen, William, and Moore, Michael (2002a). "Has the Euro Changed the Foreign Exchange Market?" Economic Policy, 17(1), pp. 149-192.

[48] Hau, Harald, Killeen, William, and Moore, Michael (2002b). "The Euro as an International Currency: Explaining Puzzling First Evidence from the Foreign Exchange Markets." Journal of International Money and Finance, 21(3), pp. 351-383.

[49] Hau, Harald and Rey, Hélène (2004). "Can Portfolio Rebalancing Explain the Dynamics of Equity Returns, Equity Flows, and Exchange Rates?" American Economic Review Papers and Proceedings, May 2004, 94(2), pp.126-133.

[50] Hau, Harald, and Rey, Hélène (2006). "Exchange Rates, Equity Prices and Capital Flows," Review of Financial Studies, Spring 2006, $19(1)$, pp. 273-317.

[51] International Monetary Fund (2005). Annual Report, 2005, Washington DC. 
[52] International Monetary Fund (2005). Direction of Trade Statistics, 2005, Washington DC.

[53] Kamps, Annette (2005). "The Euro in International Trade", mimeo, European Central Bank.

[54] Kenen, Peter (2003). "The Euro and the Dollar: Competitors or Complements?" in The European Union and the United States, Michel Dumoulin and Geneviève Duchenne (eds.), pp. 251-274.

[55] Lane, Philip R. (2005). "Global Bond Portfolios and EMU." European Central Bank (Frankfurt, Germany) Working Paper 553, November 2005.

[56] Lindert, Peter (1969). "Key Currencies and Gold: 1900-1913." Princeton Studies in International Finance No. 24. Princeton University.

[57] Lyons, Richard (2001). The Microstructure Approach to Exchange Rates. MIT Press, Cambridge, MA.

[58] Meese, Richard and Rogoff, Kenneth (1983). "Empirical Exchange Rate Models of the Seventies: Do They Fit Out of Sample?" Journal of International Economics, February 1983, 14(1), pp. 3-24.

[59] Naameh, Michael (2003). "Reserve Management in Developing Countries." in How Countries Manage Reserve Assets. Robert Pringle and Nick Carver (Eds.), Central Banking Publications, London, United Kingdom.

[60] Niehans, Jurg (1971). "Money and Barter in General Equilibrium with Transactions Costs." American Economic Review, December 1971, 61(5), pp. 773-783.

[61] Obstfeld, Maurice and Rogoff, Kenneth (1996). Foundations of International Macroeconomics. MIT Press, Cambridge (MA), USA.

[62] Obstfeld, Maurice and Rogoff, Kenneth (2005). "The Unsustainable US Current Account Position Revisited." Forthcoming in G7 Current Account Imbalances: Sustainability and Adjustment, Richard Clarida (ed.), The University of Chicago Press, Chicago, ILL.

[63] Portes, Richard, and Rey, Hélène (1998). "The Emergence of the Euro as an International Currency." Economic Policy, April 1998, 26(1), pp. 305-343. 
[64] Pringle, Robert and Carver, Nick (2003). "How Countries Manage Reserve Assets." in How Countries Manage Reserve Assets. Robert Pringle and Nick Carver (Eds.), Central Banking Publications, London, United Kingdom.

[65] Pringle, Robert and Carver, Nick (2005)."Trends in Reserve Management - Survey Results." in Reserve Management Trends. Robert Pringle and Nick Carver (Eds.), Central Banking Publications, London, United Kingdom.

[66] Reddy, Yaga Venugopal (2003). "Reserve management at the Reserve Bank of India," in How Countries Manage Reserve Assets. Robert Pringle and Nick Carver (Eds.), Central Banking Publications, London, United Kingdom.

[67] Rey, Hélène (2001). "International Trade and Currency Exchange," Review of Economic Studies, April 2001, 68(2), pp. 443-464.

[68] Royal Bank of Scotland (2003). How Countries Manage Reserve Assets. Robert Pringle and Nick Carver (Eds.), Central Banking Publications, London, United Kingdom.

[69] Royal Bank of Scotland (2005). Reserve Management Trends. Robert Pringle and Nick Carver (Eds.), Central Banking Publications, London, United Kingdom.

[70] Rose, Andrew and Spiegel, Mark M. "A Gravity Model of Sovereign Lending: Trade, Default, and Credit." National Bureau of Economic Research (Cambridge, MA) Working Paper No. 9285, October 2002.

[71] Roubini, Nouriel and Setzer, Brad (2005). "The U.S. Twin Deficits and External Debt Accumulation: Are They Sustainable?." working paper, Stern School of Business.

[72] Sarno, Lucio and Taylor Mark (2003). The Economics of Exchange Rates. Cambridge University Press, Cambridge, UK.

[73] Shioji, Etsuro (2005). "Invoicing Currency and the Optimal Basket Peg for East Asia: A New Open Economy Macroeconomics Perspective" mimeo Yokohama National University

[74] Siourounis, Gregorios (2004). "Capital Flows and Exchange Rates: An Empirical Analysis" London Business School Institute of Finance and Accounting Working Paper 400. 
[75] Snow, John (2006). Interview with Bloomberg TV, January, 13, 2006.

[76] Truman, Edwin (2005a). "Comment on "Will the Euro Eventually Surpass the Dollar as Leading International Reserve Currency? by Menzie Chinn and Jeffrey Frankel" forthcoming in G7 Current Account Imbalances: Sustainability and Adjustment, Richard Clarida (ed.), The University of Chicago Press, Chicago, IL.

[77] Truman, Edwin (2005b).Postponing Global Adjustment, Institute for International Economics Working Paper 05-6, July, Washington DC.

[78] Truman, Edwin, and Wong, Anna (2006). The Case for an International Reserve Diversification Standard, Institute for International Economics, Washington DC.

[79] World Bank (2005). Global Development Finance Database, 2005, Washington DC. 


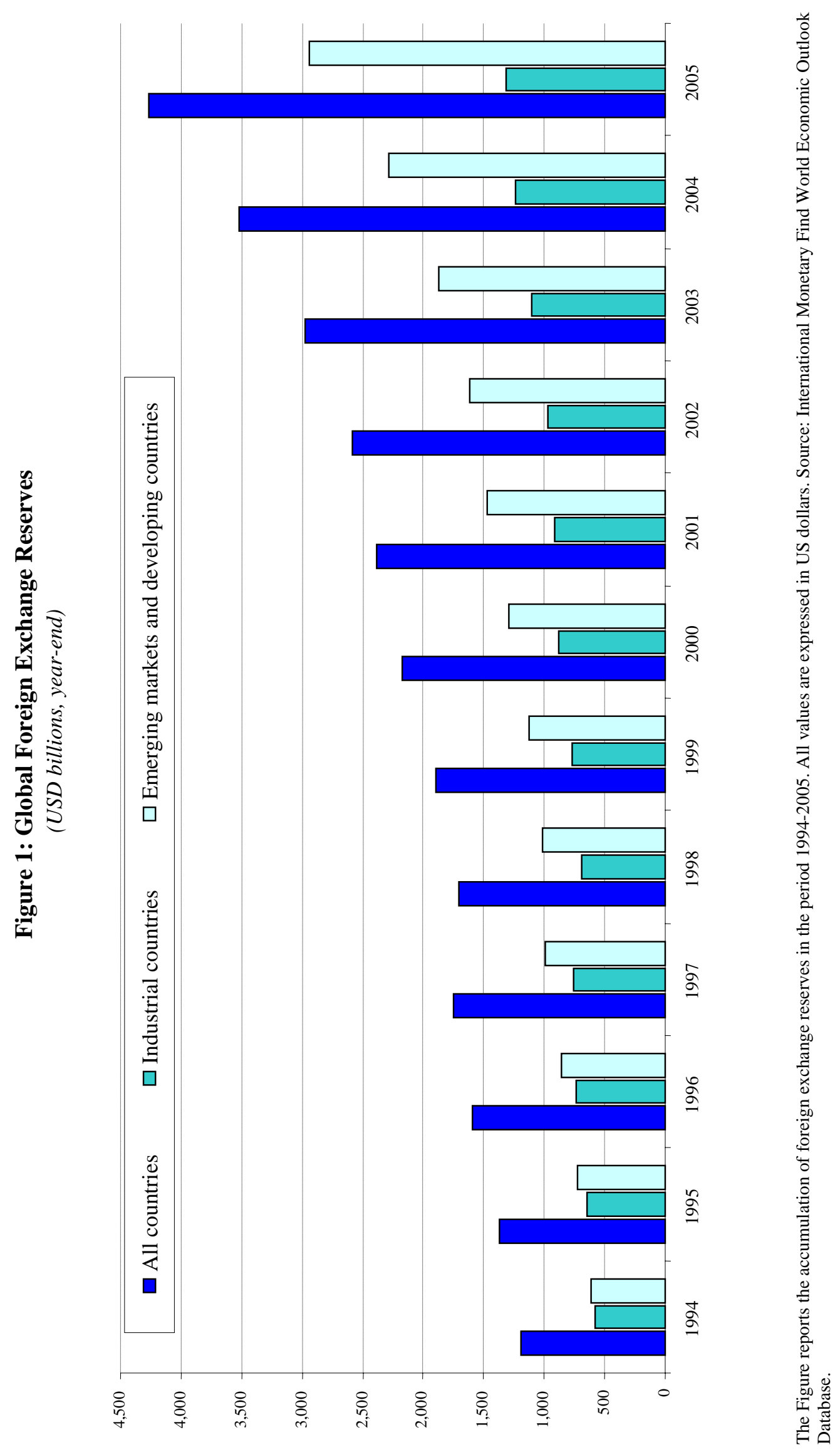




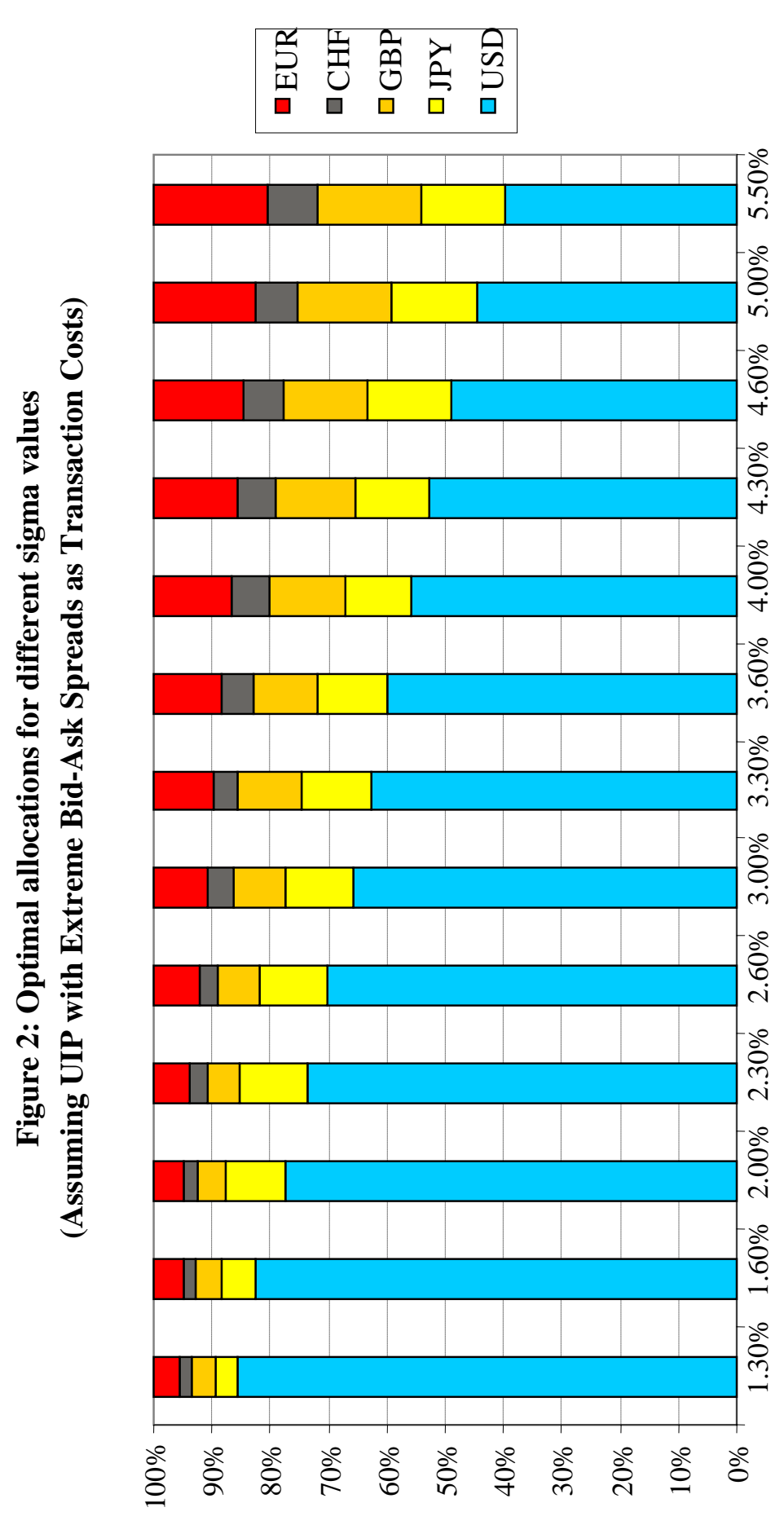

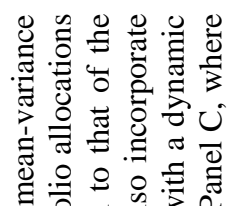

可

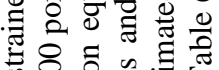

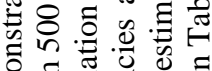

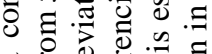

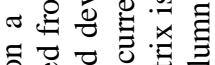

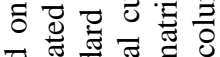

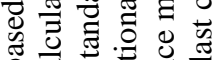

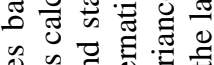

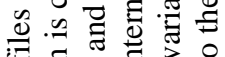

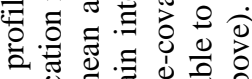

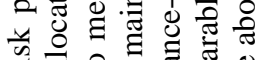

䒕。

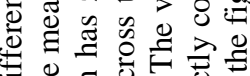

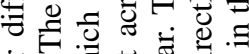

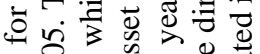

ธี О्丶

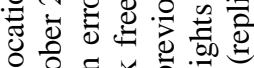

응 웡. 뜬

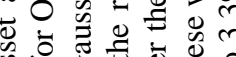

⿹气丁

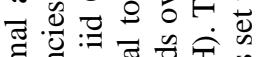

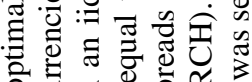

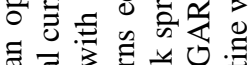

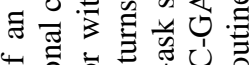

पे

䒕造过

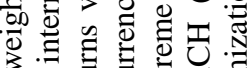

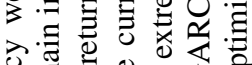

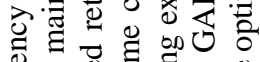

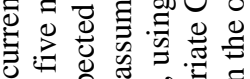

I

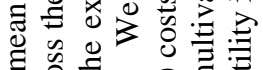

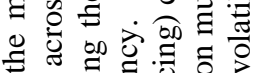

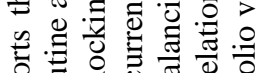

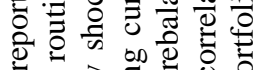

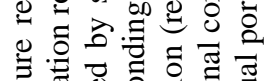

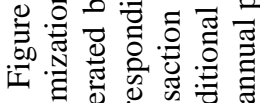

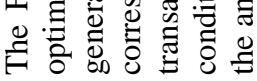


Table 1: Share of Main Currencies in Total Identified Official Holdings of Foreign Exchange

\begin{tabular}{|c|c|c|c|c|c|c|c|c|c|c|c|}
\hline & 1995 & 1996 & 1997 & 1998 & 1999 & 2000 & 2001 & 2002 & 2003 & 2004 & 2005 \\
\hline \multicolumn{12}{|l|}{ All countries } \\
\hline U.S. dollar & 59.00 & 62.10 & 65.20 & 69.40 & 71.00 & 70.50 & 70.70 & 66.50 & 65.80 & 65.90 & 66.54 \\
\hline Japanese yen & 6.80 & 6.70 & 5.80 & 6.20 & 6.40 & 6.30 & 5.20 & 4.50 & 4.10 & 3.90 & 3.58 \\
\hline Pound sterling & 2.10 & 2.70 & 2.60 & 2.70 & 2.90 & 2.80 & 2.70 & 2.90 & 2.60 & 3.30 & 3.75 \\
\hline Swiss franc & 0.30 & 0.30 & 0.30 & 0.30 & 0.20 & 0.30 & 0.30 & 0.40 & 0.20 & 0.20 & 0.14 \\
\hline Euro & - & - & - & - & 17.90 & 18.80 & 19.80 & 24.20 & 25.30 & 24.90 & 24.39 \\
\hline Deutsche mark & 15.80 & 14.70 & 14.50 & 13.80 & - & 一 & - & - & - & - & - \\
\hline French franc & 2.40 & 1.80 & 1.40 & 1.60 & - & - & - & - & - & - & - \\
\hline Netherlands guilder & 0.30 & 0.20 & 0.40 & 0.30 & - & - & - & - & - & - & - \\
\hline ECU & 8.50 & 7.10 & 6.00 & 1.20 & - & - & - & - & - & - & - \\
\hline Other currencies & 4.80 & 4.30 & 3.80 & 4.50 & 1.60 & 1.40 & 1.20 & 1.40 & 1.90 & 1.80 & 1.60 \\
\hline
\end{tabular}

Industrial Countries

$\begin{array}{lcccccccccccc}\text { U.S. dollar } & 52.30 & 57.40 & 59.10 & 67.60 & 73.50 & 72.50 & 72.70 & 68.90 & 70.50 & 71.50 & 73.71 \\ \text { Japanese yen } & 6.70 & 5.70 & 5.90 & 6.90 & 6.70 & 6.50 & 5.60 & 4.40 & 3.80 & 3.60 & 3.32 \\ \text { Pound sterling } & 2.10 & 2.10 & 2.00 & 2.10 & 2.20 & 2.00 & 1.90 & 2.10 & 1.50 & 1.90 & 2.11 \\ \text { Swiss franc } & 0.10 & 0.10 & 0.10 & 0.20 & 0.10 & 0.20 & 0.30 & 0.60 & 0.20 & 0.10 & 0.13 \\ \text { Euro } & - & - & - & - & 16.10 & 17.10 & 18.00 & 22.40 & 22.10 & 20.90 & 19.15 \\ \text { Deutsche mark } & 16.60 & 15.90 & 16.20 & 13.40 & - & - & - & - & - & - & - & - \\ \text { French franc } & 2.30 & 1.70 & 0.90 & 1.20 & - & - & - & - & - & - \\ \text { Netherlands guilder } & 0.20 & 0.20 & 0.20 & 0.20 & - & - & - & - & - & - \\ \text { ECU } & 13.60 & 12.30 & 11.20 & 2.30 & - & - & - & - & - & - \\ \text { Other currencies } & 6.00 & 4.70 & 4.40 & 6.20 & 1.40 & 1.60 & 1.50 & 1.70 & 1.90 & 2.00 & 1.58\end{array}$

Developing Countries

\begin{tabular}{|c|c|c|c|c|c|c|c|c|c|c|c|}
\hline U.S. dollar & 70.30 & 68.50 & 72.40 & 71.20 & 68.20 & 68.20 & 68.60 & 64.00 & 60.70 & 59.90 & 60.49 \\
\hline Japanese yen & 7.00 & 8.10 & 5.70 & 5.60 & 6.00 & 6.00 & 4.90 & 4.70 & 4.40 & 4.30 & 3.81 \\
\hline Pound sterling & 2.20 & 3.50 & 3.30 & 3.30 & 3.70 & 3.60 & 3.60 & 3.80 & 3.90 & 4.80 & 5.13 \\
\hline Swiss franc & 0.70 & 0.60 & 0.60 & 0.50 & 0.40 & 0.30 & 0.30 & 0.20 & 0.20 & 0.20 & 0.15 \\
\hline Euro & - & - & - & - & 19.90 & 20.60 & 21.80 & 26.10 & 28.90 & 29.20 & 28.80 \\
\hline Deutsche mark & 14.40 & 13.00 & 12.50 & 14.30 & - & - & - & - & - & - & - \\
\hline French franc & 2.40 & 2.00 & 2.10 & 2.10 & - & - & - & - & - & - & - \\
\hline Netherlands guilder & 0.50 & 0.30 & 0.50 & 0.40 & - & - & - & - & - & - & - \\
\hline ECU & 0.00 & 0.00 & 0.00 & 0.00 & - & - & - & - & - & - & - \\
\hline Other currencies & 2.60 & 3.90 & 3.00 & 2.70 & 1.70 & 1.30 & 0.90 & 1.20 & 1.90 & 1.60 & 1.61 \\
\hline
\end{tabular}

Source: International Monetary Fund (IMF) 2005 Annual Report.

Country coverage changes every year (so the observations are not fully comparable across years). ECU reserves held by the monetary authorities existed in the form of claims on both the private sector and the European Monetary Institute (EMI), which issued official ECUs to European Union central banks through revolving swaps against the contribution of 20 percent of their gross gold holdings and U. S. dollar reserves. On December 31, 1998, the official ECUs were unwound into gold and U.S. dollars; hence, the share of ECUs at the end of 1998 was sharply lower than a year earlier. The remaining ECU holdings reported for 1998 consisted of ECUs issued by the private sector, usually in the form of ECU deposits and bonds. On January 1, 1999, these holdings were automatically converted into euros. All shares are estimated at the end of year. The 2005 values are based on preliminary data from the IMF COFER database. 


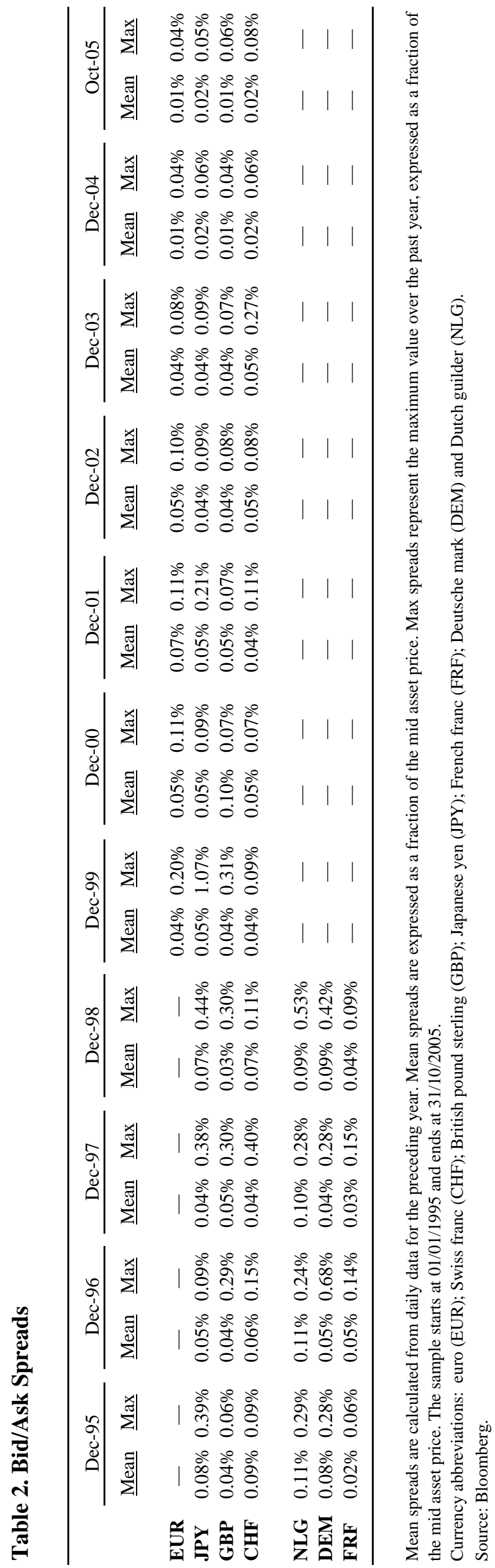




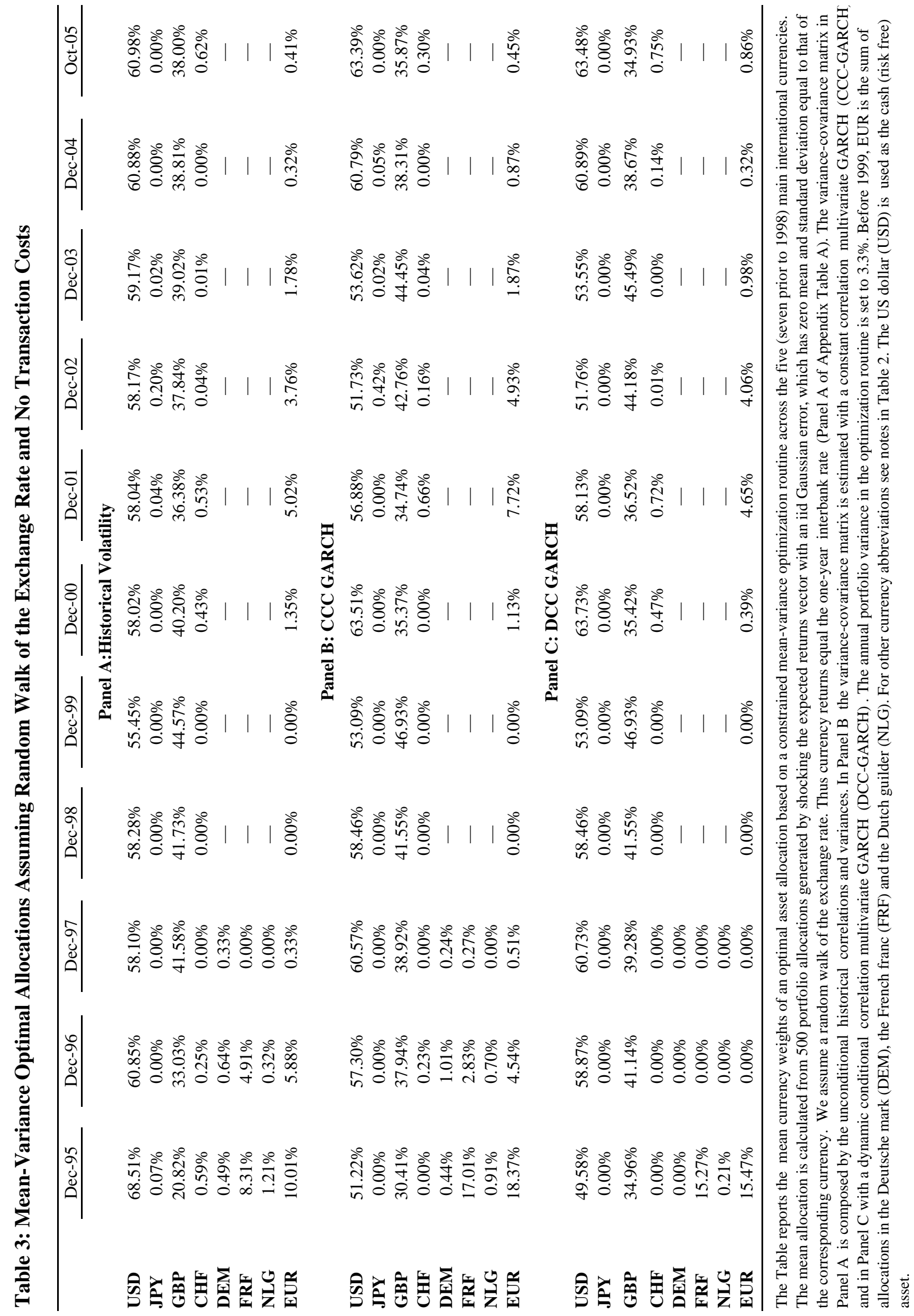




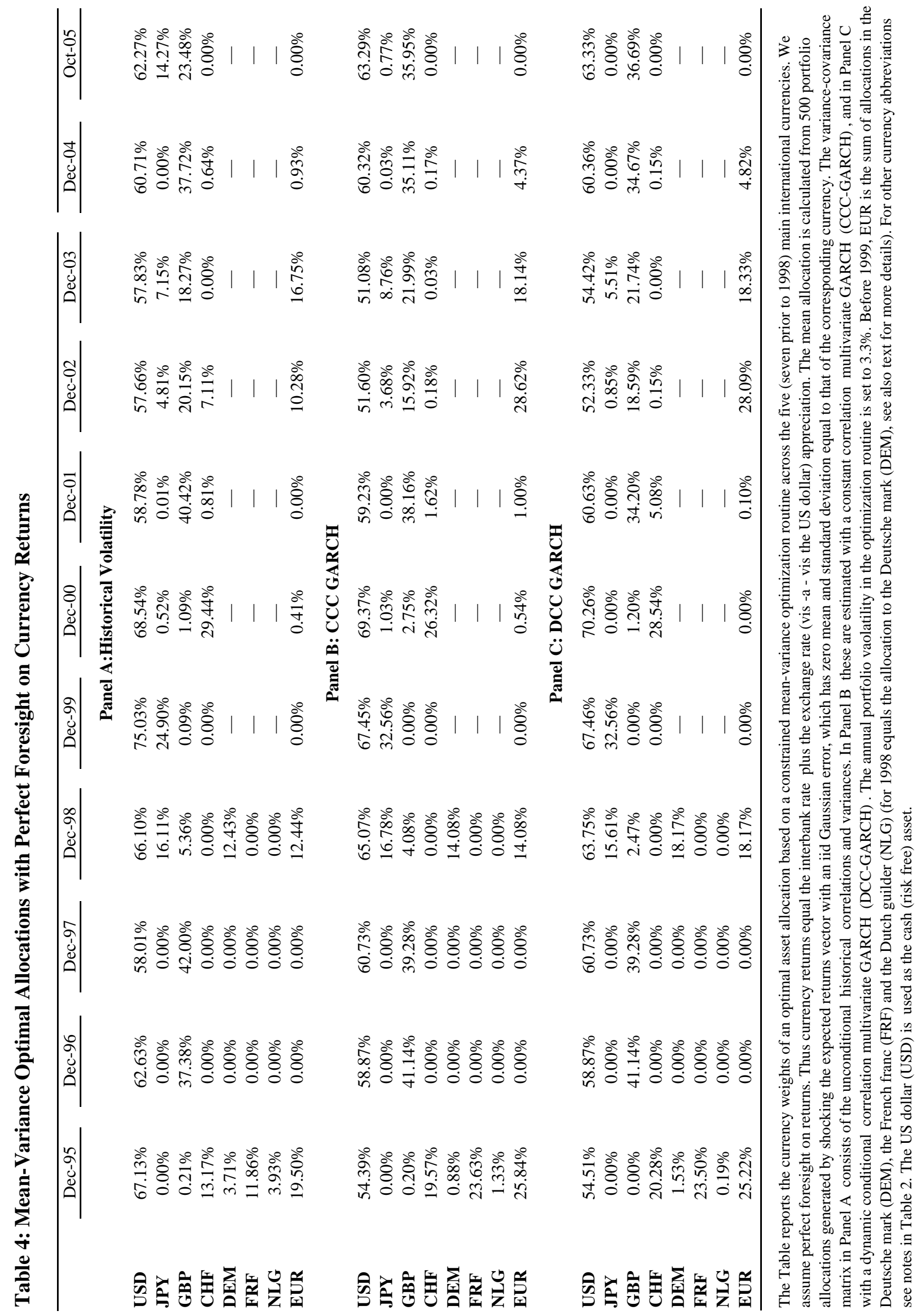




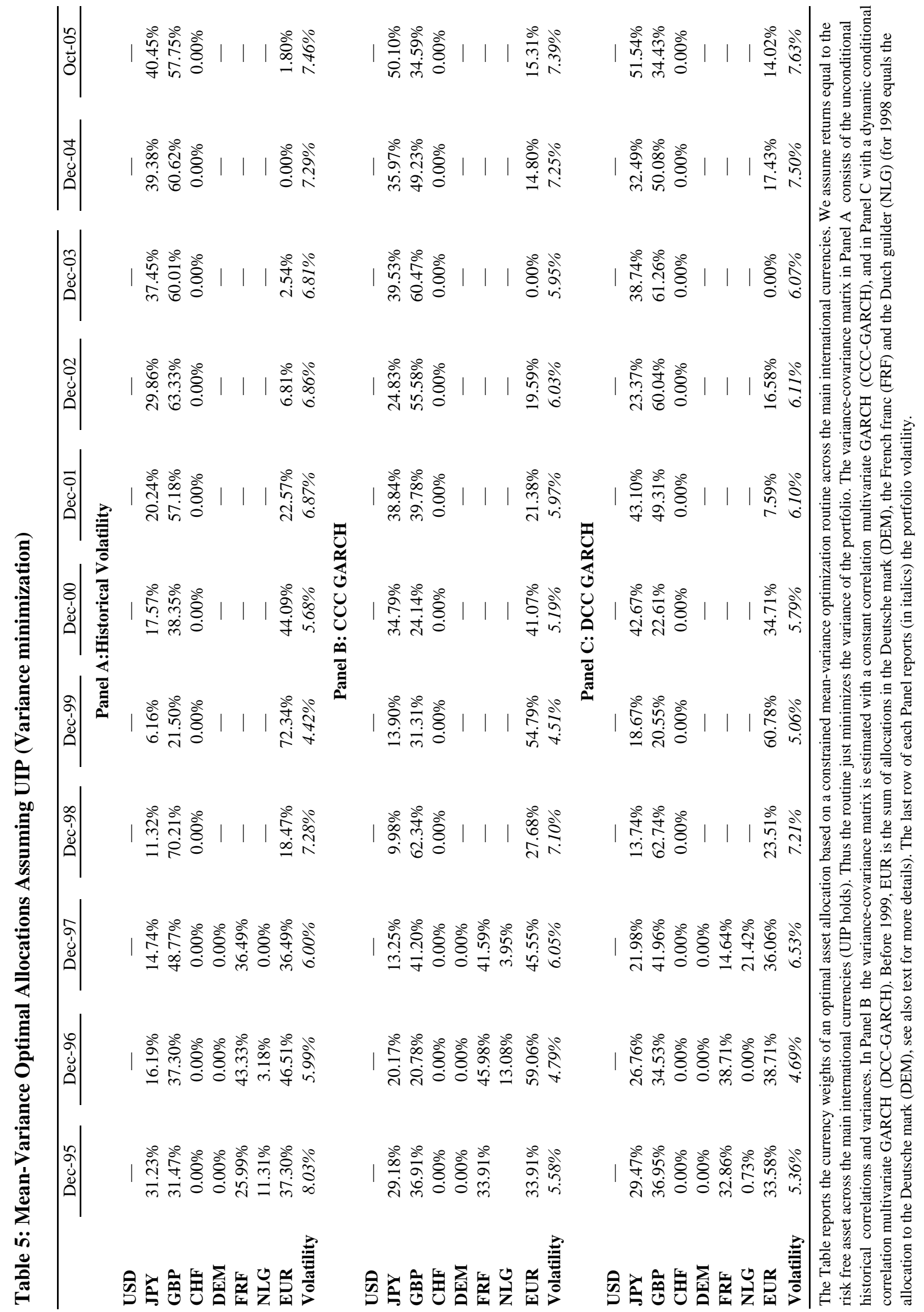




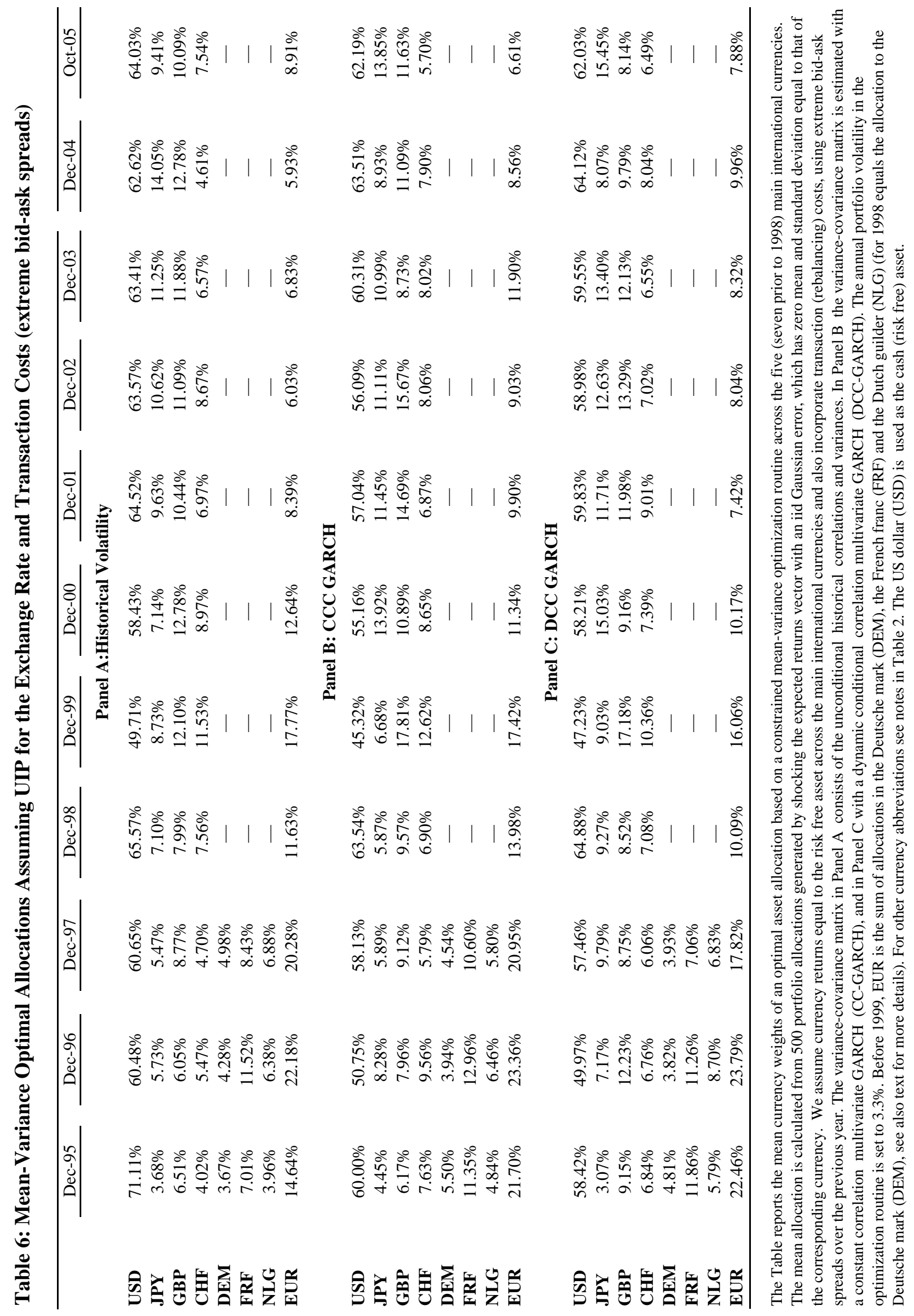




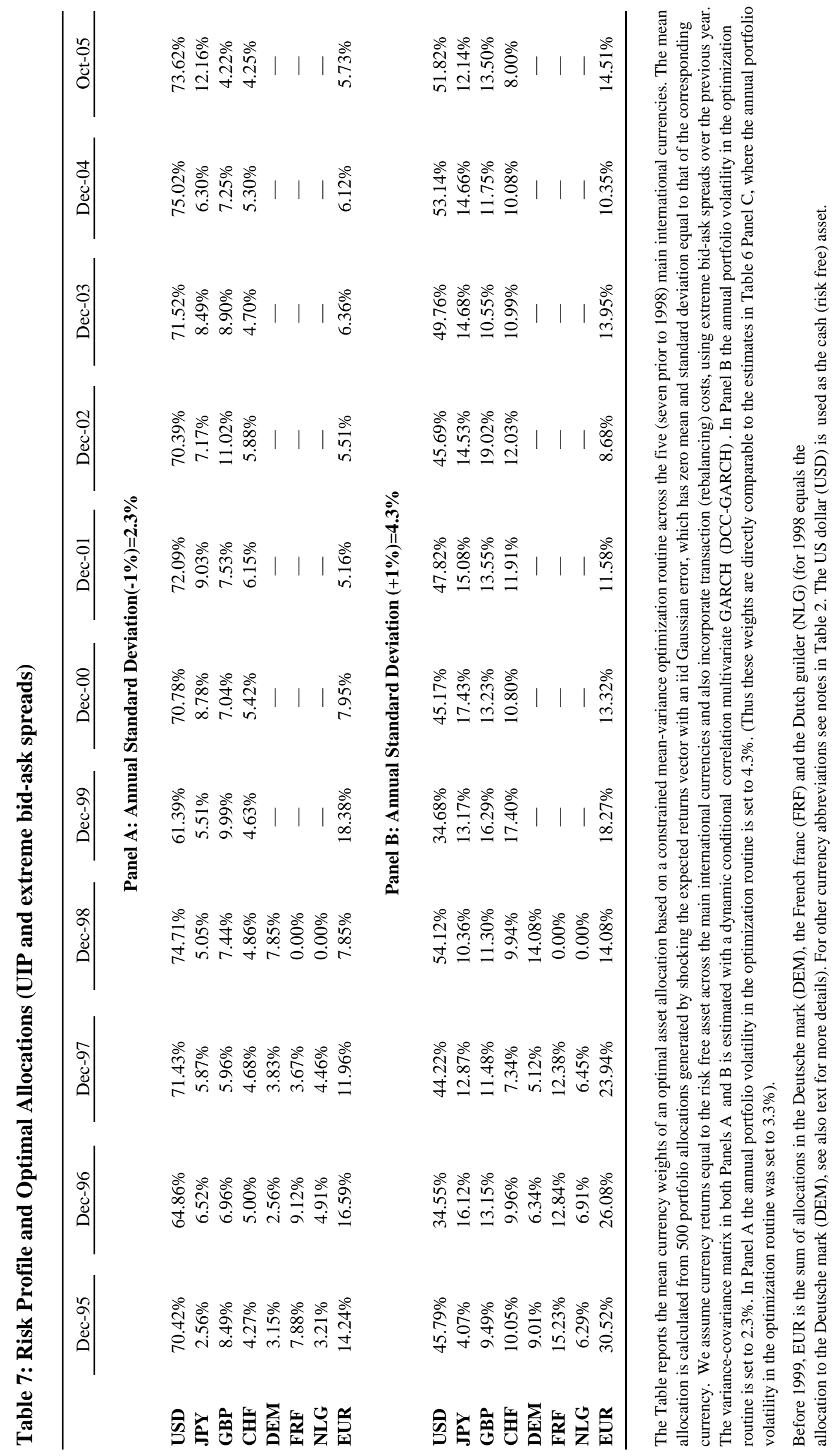




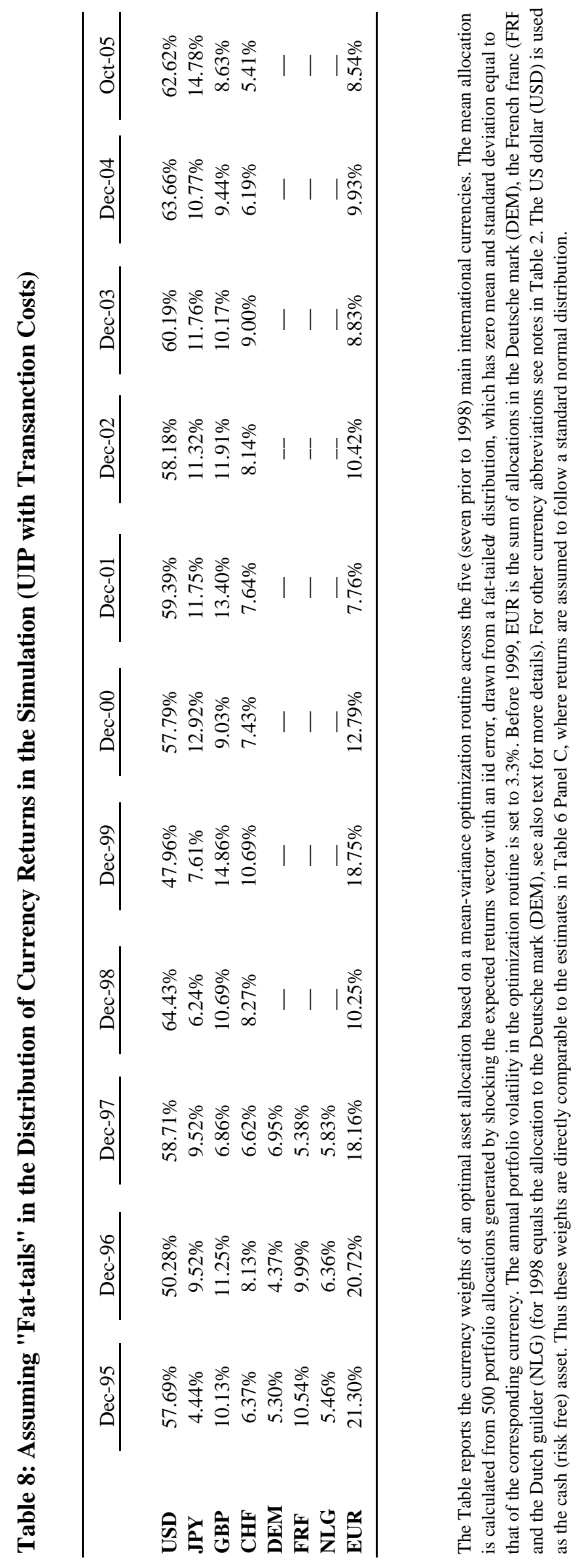




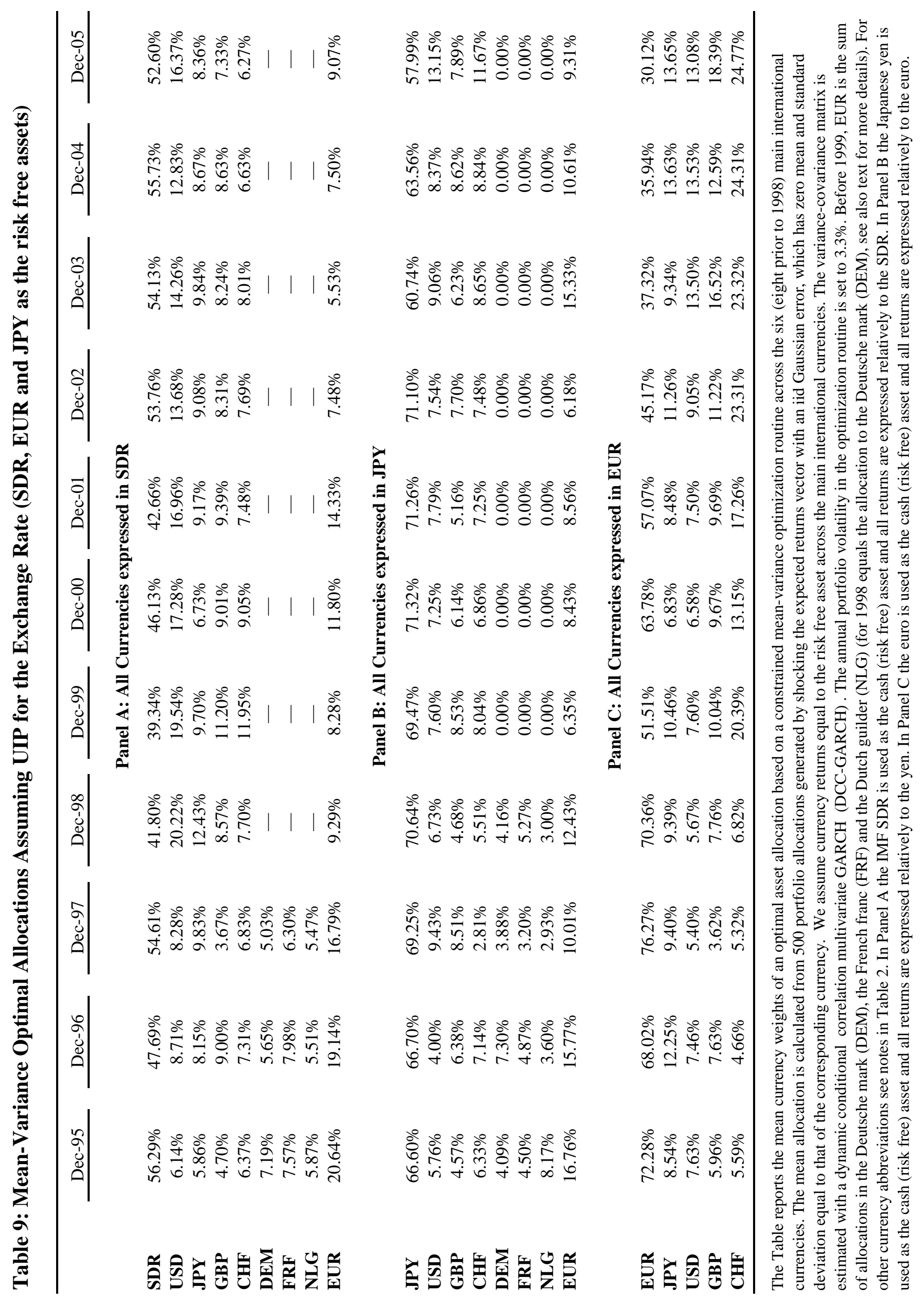




\begin{tabular}{|c|c|c|c|c|c|c|c|c|c|}
\hline & Dec-95 & Dec-96 & Dec-97 & Dec-98 & Dec-99 & Dec-00 & Dec-01 & Dec-02 & Dec-03 \\
\hline & \multicolumn{9}{|c|}{ Panel A: Russia } \\
\hline USD & $56.75 \%$ & $48.86 \%$ & $56.87 \%$ & $61.95 \%$ & $46.60 \%$ & $56.65 \%$ & $59.58 \%$ & $57.06 \%$ & $59.99 \%$ \\
\hline JPY & $4.06 \%$ & $8.68 \%$ & $8.01 \%$ & $5.25 \%$ & $6.32 \%$ & $10.67 \%$ & $9.21 \%$ & $10.49 \%$ & $8.91 \%$ \\
\hline GBP & $4.89 \%$ & $8.47 \%$ & $7.92 \%$ & $7.98 \%$ & $11.85 \%$ & $8.69 \%$ & $7.83 \%$ & $8.67 \%$ & $8.05 \%$ \\
\hline CHF & $5.45 \%$ & $5.17 \%$ & $3.83 \%$ & $6.09 \%$ & $11.95 \%$ & $7.78 \%$ & $6.37 \%$ & $6.01 \%$ & $4.45 \%$ \\
\hline DEM & $19.22 \%$ & $20.06 \%$ & $18.66 \%$ & - & - & - & - & - & - \\
\hline FRF & $9.56 \%$ & $8.71 \%$ & $4.63 \%$ & - & - & - & - & - & - \\
\hline EUR & $28.77 \%$ & $28.76 \%$ & $23.29 \%$ & $18.66 \%$ & $23.14 \%$ & $16.18 \%$ & $16.97 \%$ & $17.76 \%$ & $18.57 \%$ \\
\hline
\end{tabular}

\section{Panel B: India}

$\begin{array}{lccccccccc}\text { USD } & 53.22 \% & 46.24 \% & 56.14 \% & 62.97 \% & 47.62 \% & 55.43 \% & 57.27 \% & 55.71 \% & 58.15 \% \\ \text { JPY } & 10.42 \% & 15.62 \% & 11.19 \% & 11.38 \% & 12.60 \% & 14.51 \% & 14.93 \% & 13.50 \% & 13.53 \% \\ \text { GBP } & 8.72 \% & 10.54 \% & 9.67 \% & 7.74 \% & 14.72 \% & 8.27 \% & 10.22 \% & 11.52 \% & 9.73 \% \\ \text { CHF } & 6.24 \% & 7.27 \% & 5.24 \% & 5.32 \% & 12.18 \% & 8.40 \% & 7.46 \% & 6.05 \% & 7.93 \% \\ \text { DEM } & 7.70 \% & 6.94 \% & 8.61 \% & - & - & - & - & - \\ \text { FRF } & 13.62 \% & 13.33 \% & 9.05 \% & - & - & - & - & - \\ \text { EUR } & 21.32 \% & 20.27 \% & 17.66 \% & 12.51 \% & 12.76 \% & 13.37 \% & 10.08 \% & 13.19 \% & 10.63 \%\end{array}$

\section{Panel C: China}

$\begin{array}{lccccccccc}\text { USD } & 54.50 \% & 46.39 \% & 56.62 \% & 63.39 \% & 48.47 \% & 54.67 \% & 57.75 \% & 55.86 \% & 58.30 \% \\ \text { JPY } & 13.16 \% & 16.29 \% & 13.00 \% & 11.30 \% & 13.05 \% & 16.01 \% & 15.73 \% & 13.56 \% & 15.95 \% \\ \text { GBP } & 10.32 \% & 13.08 \% & 9.23 \% & 7.55 \% & 10.61 \% & 8.38 \% & 8.64 \% & 12.61 \% & 7.47 \% \\ \text { CHF } & 6.88 \% & 6.43 \% & 7.27 \% & 7.03 \% & 13.31 \% & 8.70 \% & 7.46 \% & 8.68 \% \\ \text { DEM } & 5.09 \% & 5.49 \% & 6.43 \% & - & - & - & - & - & - \\ \text { FRF } & 9.97 \% & 12.26 \% & 7.35 \% & - & - & - & - & - \\ \text { EUR } & 15.05 \% & 17.74 \% & 13.78 \% & 10.65 \% & 14.44 \% & 12.20 \% & 10.37 \% & 9.26 \% & 10.67 \%\end{array}$

\section{Panel D: Brazil}

\begin{tabular}{lccccccccc} 
USD & $55.18 \%$ & $46.98 \%$ & $57.14 \%$ & $62.46 \%$ & $47.57 \%$ & $56.43 \%$ & $58.05 \%$ & $57.07 \%$ & $58.82 \%$ \\
JPY & $7.01 \%$ & $11.95 \%$ & $10.15 \%$ & $8.34 \%$ & $10.38 \%$ & $12.23 \%$ & $11.09 \%$ & $11.40 \%$ & $13.30 \%$ \\
GBP & $8.08 \%$ & $10.94 \%$ & $8.44 \%$ & $9.54 \%$ & $13.78 \%$ & $10.67 \%$ & $8.80 \%$ & $9.04 \%$ & $8.97 \%$ \\
CHF & $8.46 \%$ & $8.76 \%$ & $7.83 \%$ & $6.43 \%$ & $11.26 \%$ & $9.42 \%$ & $6.32 \%$ & $7.89 \%$ & $7.74 \%$ \\
DEM & $7.95 \%$ & $7.24 \%$ & $7.71 \%$ & - & - & - & - & - \\
FRF & $13.26 \%$ & $14.08 \%$ & $8.63 \%$ & - & - & - & - & - \\
EUR & $21.20 \%$ & $21.32 \%$ & $16.34 \%$ & $13.12 \%$ & $16.86 \%$ & $11.23 \%$ & $15.70 \%$ & $14.57 \%$ & $11.13 \%$ \\
\hline
\end{tabular}

The Table reports the currency weights of an optimal asset allocation based on a constrained mean-variance optimization routine across the five (seven prior to 1998) main international currencies for Russia, India, China and Brazil. The variance-covariance matrix is estimated with a dynamic conditional correlation multivariate GARCH. The annual portfolio volatility in the optimization routine is set to $3.3 \%$. We assume currency returns equal to the risk free asset across the main international currencies and also incorporate transaction (rebalancing) costs, using extreme bid-ask spreads over the previous year. Before 1999, EUR is the sum of allocations in the Deutsche mark (DEM), the French franc (FRF) and the Dutch guilder (NLG) (for 1998 equals the allocation to the Deutsche mark (DEM), see also text for more details). For other currency abbreviations see notes in Table 2. The US dollar (USD) is the risk free asset.

The constraints are based on currency composition of external (total) debt. The table reports the weights imposing as a constraint that the central bank holds reserves in the currencies of the country's external debt at levels at least equal to $50 \%$ of the share of its debt in each currency. 
Table 11: Simulated Optimal Allocations for Selected Developing Countries with Direction of Trade as Constraint

\begin{tabular}{|c|c|c|c|c|c|c|c|c|c|c|}
\hline & Dec-95 & Dec-96 & Dec-97 & Dec-98 & Dec-99 & Dec-00 & Dec-01 & Dec-02 & Dec-03 & Dec-04 \\
\hline & \multicolumn{10}{|c|}{ Panel A: Russia } \\
\hline USD & $55.73 \%$ & $48.49 \%$ & $56.24 \%$ & $62.21 \%$ & $43.07 \%$ & $52.47 \%$ & $58.74 \%$ & $54.75 \%$ & $60.65 \%$ & $61.86 \%$ \\
\hline JPY & $5.91 \%$ & $10.60 \%$ & $8.44 \%$ & $8.14 \%$ & $10.21 \%$ & $11.72 \%$ & $7.06 \%$ & $8.15 \%$ & $6.91 \%$ & $4.98 \%$ \\
\hline GBP & $8.25 \%$ & $10.06 \%$ & $10.67 \%$ & $8.27 \%$ & $10.21 \%$ & $5.89 \%$ & $5.88 \%$ & $9.41 \%$ & $5.30 \%$ & $4.69 \%$ \\
\hline CHF & $5.83 \%$ & $6.06 \%$ & $4.88 \%$ & $5.81 \%$ & $8.12 \%$ & $4.72 \%$ & $2.89 \%$ & $3.66 \%$ & $3.30 \%$ & $3.59 \%$ \\
\hline DEM & 8.95\% & $8.62 \%$ & $8.18 \%$ & - & - & - & - & - & - & - \\
\hline FRF & $10.67 \%$ & $9.00 \%$ & $5.70 \%$ & - & - & - & - & - & - & - \\
\hline NLG & $4.58 \%$ & $7.10 \%$ & $5.80 \%$ & - & - & - & - & - & - & - \\
\hline EUR & $24.21 \%$ & $24.72 \%$ & $19.68 \%$ & $15.46 \%$ & $28.25 \%$ & $25.18 \%$ & $25.40 \%$ & $24.03 \%$ & $23.83 \%$ & $24.88 \%$ \\
\hline
\end{tabular}

Panel B: India

$\begin{array}{lcccccccccc}\text { USD } & 57.26 \% & 48.22 \% & 57.04 \% & 62.54 \% & 47.20 \% & 56.60 \% & 57.16 \% & 56.88 \% & 58.56 \% & 62.63 \% \\ \text { JPY } & 7.06 \% & 10.24 \% & 7.93 \% & 6.63 \% & 7.69 \% & 12.20 \% & 11.96 \% & 9.08 \% & 10.07 \% & 9.18 \% \\ \text { GBP } & 8.17 \% & 13.21 \% & 10.33 \% & 8.81 \% & 12.40 \% & 8.82 \% & 13.04 \% & 12.56 \% & 12.53 \% & 10.39 \% \\ \text { CHF } & 7.42 \% & 7.49 \% & 5.76 \% & 7.63 \% & 11.76 \% & 9.46 \% & 3.96 \% & 8.62 \% & 7.15 \% & 6.89 \% \\ \text { DEM } & 5.89 \% & 5.22 \% & 5.65 \% & - & - & - & - & - & - & - \\ \text { FRF } & 8.40 \% & 10.93 \% & 6.79 \% & - & - & - & - & - & - & - \\ \text { NLG } & 5.74 \% & 4.61 \% & 6.39 \% & - & - & - & - & - & - & - \\ \text { EUR } & 20.03 \% & 20.76 \% & 18.83 \% & 14.27 \% & 20.81 \% & 12.89 \% & 13.83 \% & 12.83 \% & 11.65 \% & 10.90 \%\end{array}$

\section{Panel C: China}

$\begin{array}{lcccccccccc}\text { USD } & 52.54 \% & 45.63 \% & 56.65 \% & 62.73 \% & 45.04 \% & 52.98 \% & 54.89 \% & 54.71 \% & 56.20 \% & 56.32 \% \\ \text { JPY } & 16.24 \% & 15.63 \% & 14.76 \% & 13.17 \% & 14.39 \% & 17.29 \% & 17.48 \% & 15.42 \% & 19.05 \% & 16.92 \% \\ \text { GBP } & 8.40 \% & 11.98 \% & 8.02 \% & 8.96 \% & 11.83 \% & 9.06 \% & 10.75 \% & 10.97 \% & 8.82 \% & 9.97 \% \\ \text { CHF } & 3.87 \% & 5.14 \% & 4.23 \% & 4.92 \% & 8.57 \% & 6.74 \% & 4.87 \% & 6.28 \% & 5.01 \% & 5.82 \% \\ \text { DEM } & 5.14 \% & 5.23 \% & 5.05 \% & - & - & - & - & - & - & - \\ \text { FRF } & 9.49 \% & 10.83 \% & 6.28 \% & - & - & - & - & - & - & - \\ \text { NLG } & 4.22 \% & 5.48 \% & 4.92 \% & - & - & - & - & - & - & - \\ \text { EUR } & 18.85 \% & 21.55 \% & 16.24 \% & 10.11 \% & 20.04 \% & 13.91 \% & 11.97 \% & 12.60 \% & 10.89 \% & 10.95 \%\end{array}$

\section{Panel D: Brazil}

\begin{tabular}{lcccccccccc} 
USD & $55.80 \%$ & $49.28 \%$ & $57.03 \%$ & $61.99 \%$ & $45.43 \%$ & $53.81 \%$ & $57.61 \%$ & $55.78 \%$ & $59.11 \%$ & $62.01 \%$ \\
JPY & $6.45 \%$ & $9.76 \%$ & $8.18 \%$ & $7.71 \%$ & $8.71 \%$ & $12.30 \%$ & $11.07 \%$ & $9.08 \%$ & $11.25 \%$ & $8.79 \%$ \\
GBP & $6.62 \%$ & $9.05 \%$ & $8.18 \%$ & $7.84 \%$ & $13.52 \%$ & $8.48 \%$ & $8.00 \%$ & $11.43 \%$ & $7.82 \%$ & $8.02 \%$ \\
CHF & $6.23 \%$ & $8.41 \%$ & $5.34 \%$ & $5.22 \%$ & $10.00 \%$ & $6.22 \%$ & $5.62 \%$ & $7.61 \%$ & $5.49 \%$ & $6.61 \%$ \\
DEM & $7.62 \%$ & $6.34 \%$ & $7.00 \%$ & - & - & - & - & - & - & - \\
FRF & $11.84 \%$ & $10.28 \%$ & $7.78 \%$ & - & - & - & - & - & - & - \\
NLG & $5.37 \%$ & $6.81 \%$ & $6.39 \%$ & - & - & - & - & - & - & - \\
EUR & $24.83 \%$ & $23.43 \%$ & $21.17 \%$ & $17.12 \%$ & $22.20 \%$ & $19.16 \%$ & $17.68 \%$ & $16.07 \%$ & $16.28 \%$ & $14.56 \%$ \\
\hline
\end{tabular}

The Table reports the currency weights of an optimal asset allocation based on a constrained mean-variance optimization routine across the five (seven prior to 1998) main international currencies for Russia, India, China and Brazil. The variance-covariance matrix is estimated with a dynamic conditional correlation multivariate GARCH. The annual portfolio volatility in the optimization routine is set to $3.3 \%$. We assume currency returns equal to the risk free asset across the main international currencies and also incorporate transaction (rebalancing) costs, using extreme bid-ask spreads over the previous year. Before 1999, EUR is the sum of allocations in the Deutsche mark (DEM), the French franc (FRF) and the Dutch guilder (NLG) (for 1998 equals the allocation to the Deutsche mark (DEM), see also text for more details). For other currency abbreviations see notes in Table 2. The US dollar (USD) is the risk free asset.

The constraints are based on the trade share with the corresponding developed countries. The trade share is defined as exports plus imports relatively to total (world) trade. The table reports the weights imposing as a constraint that the central bank holds reserves in the currencies of the country's main trade partners at levels equal to $50 \%$ of the share of international trade with each partner. 
Table 12: Simulated Optimal Allocations for Selected Developing Countries with Direction of Trade as Constraint (Minimum Variance Portfolio Weights)

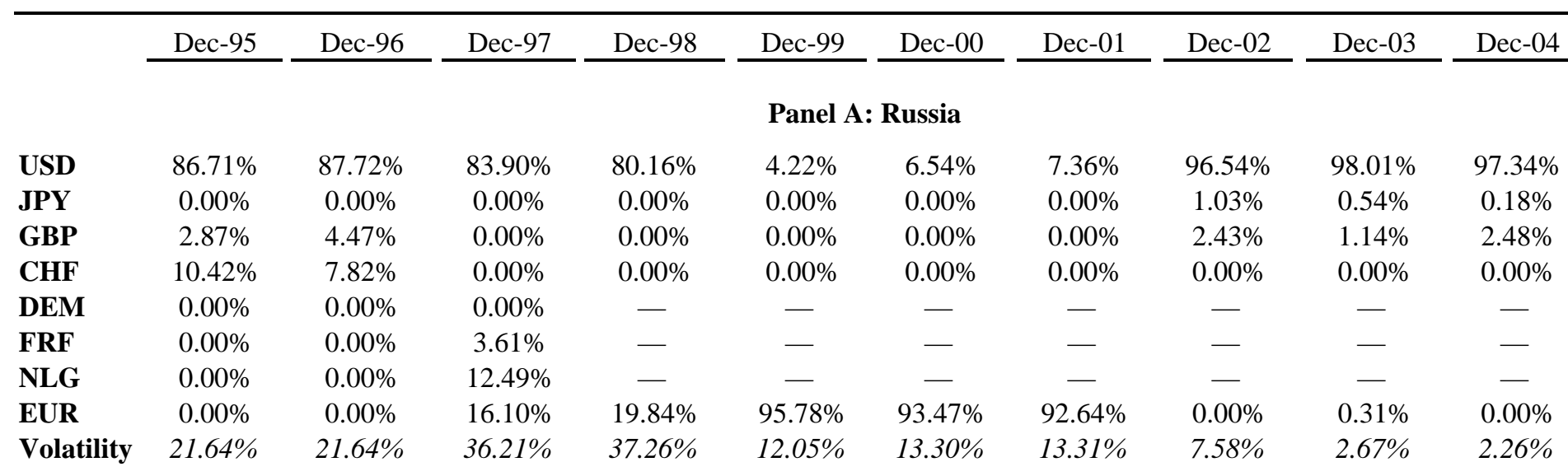

\begin{tabular}{|c|c|c|c|c|c|c|c|c|c|c|}
\hline USD & $87.60 \%$ & $87.51 \%$ & $87.74 \%$ & $87.67 \%$ & $46.49 \%$ & $67.74 \%$ & $86.86 \%$ & $86.69 \%$ & $87.18 \%$ & $87.87 \%$ \\
\hline JPY & $3.36 \%$ & $3.08 \%$ & $2.70 \%$ & $2.70 \%$ & $2.50 \%$ & $2.03 \%$ & $1.99 \%$ & $1.69 \%$ & $1.56 \%$ & $1.38 \%$ \\
\hline GBP & $2.74 \%$ & $2.89 \%$ & $2.97 \%$ & $2.97 \%$ & $2.79 \%$ & $2.84 \%$ & $2.54 \%$ & $2.35 \%$ & $2.22 \%$ & $1.94 \%$ \\
\hline CHF & $0.81 \%$ & $0.89 \%$ & $1.73 \%$ & $2.11 \%$ & $1.81 \%$ & $1.85 \%$ & $0.36 \%$ & $1.30 \%$ & $1.29 \%$ & $1.63 \%$ \\
\hline DEM & $3.50 \%$ & $3.36 \%$ & $2.99 \%$ & - & - & - & - & - & - & - \\
\hline FRF & $1.10 \%$ & $1.25 \%$ & $1.02 \%$ & - & - & - & - & - & - & - \\
\hline NLG & $0.90 \%$ & $1.01 \%$ & $0.84 \%$ & - & - & - & - & - & - & - \\
\hline EUR & $5.49 \%$ & $5.63 \%$ & $4.86 \%$ & $4.55 \%$ & $46.41 \%$ & $25.53 \%$ & $8.26 \%$ & $7.97 \%$ & $7.74 \%$ & 7.19\% \\
\hline Volatility & $7.84 \%$ & $6.86 \%$ & $5.26 \%$ & $6.06 \%$ & $3.69 \%$ & $4.35 \%$ & $3.07 \%$ & $2.27 \%$ & $2.36 \%$ & $2.86 \%$ \\
\hline & \multicolumn{10}{|c|}{ Panel C: China } \\
\hline USD & - & - & $85.87 \%$ & $85.81 \%$ & $83.09 \%$ & 83.92\% & $83.71 \%$ & $84.52 \%$ & $84.52 \%$ & $85.19 \%$ \\
\hline JPY & - & - & $9.35 \%$ & $8.95 \%$ & $9.17 \%$ & $8.77 \%$ & $8.61 \%$ & $8.21 \%$ & $7.85 \%$ & $7.27 \%$ \\
\hline GBP & - & - & $0.89 \%$ & $1.02 \%$ & $1.09 \%$ & $1.04 \%$ & $1.01 \%$ & $0.92 \%$ & 0.85\% & $0.85 \%$ \\
\hline CHF & - & - & $0.23 \%$ & $0.22 \%$ & $0.23 \%$ & $0.23 \%$ & $0.23 \%$ & $0.22 \%$ & $0.21 \%$ & $0.22 \%$ \\
\hline DEM & - & - & $1.95 \%$ & - & - & - & - & - & - & - \\
\hline FRF & - & - & $0.86 \%$ & - & - & - & - & - & - & - \\
\hline NLG & - & - & $0.84 \%$ & - & - & - & - & - & - & - \\
\hline EUR & - & - & $3.65 \%$ & $4.00 \%$ & $6.41 \%$ & $6.03 \%$ & $6.44 \%$ & $6.14 \%$ & $6.58 \%$ & $6.47 \%$ \\
\hline \multirow[t]{2}{*}{ Volatility } & - & - & $1.36 \%$ & $1.52 \%$ & $1.30 \%$ & $1.35 \%$ & $1.25 \%$ & $1.26 \%$ & $1.23 \%$ & $1.21 \%$ \\
\hline & \multicolumn{10}{|c|}{ Panel D: Brazil } \\
\hline USD & $88.25 \%$ & $88.77 \%$ & $88.92 \%$ & 91.81\% & $75.82 \%$ & $79.02 \%$ & 79.73\% & $84.32 \%$ & $85.05 \%$ & $85.78 \%$ \\
\hline JPY & $3.32 \%$ & $2.85 \%$ & $2.88 \%$ & $2.52 \%$ & $9.46 \%$ & $7.97 \%$ & $6.49 \%$ & $2.08 \%$ & $2.00 \%$ & $1.78 \%$ \\
\hline GBP & $1.19 \%$ & $1.26 \%$ & $1.19 \%$ & $1.30 \%$ & $1.35 \%$ & $1.17 \%$ & $1.27 \%$ & $1.45 \%$ & $1.27 \%$ & $1.08 \%$ \\
\hline CHF & $0.57 \%$ & $0.61 \%$ & $0.51 \%$ & $0.53 \%$ & $0.51 \%$ & $0.76 \%$ & $0.63 \%$ & $0.64 \%$ & $0.54 \%$ & $0.46 \%$ \\
\hline DEM & $3.64 \%$ & $3.44 \%$ & $3.38 \%$ & - & - & - & - & - & - & - \\
\hline FRF & $1.27 \%$ & $1.12 \%$ & $1.22 \%$ & - & - & - & - & - & - & - \\
\hline NLG & $1.76 \%$ & $1.96 \%$ & $1.90 \%$ & - & - & - & - & - & - & - \\
\hline EUR & $6.67 \%$ & $6.51 \%$ & $6.51 \%$ & $3.83 \%$ & $12.86 \%$ & $11.08 \%$ & $11.88 \%$ & $11.51 \%$ & $11.15 \%$ & $10.90 \%$ \\
\hline Volatility & $23.92 \%$ & $13.70 \%$ & $9.83 \%$ & $2.81 \%$ & $13.91 \%$ & $14.46 \%$ & $16.84 \%$ & $18.43 \%$ & $18.41 \%$ & $18.81 \%$ \\
\hline
\end{tabular}

The Table reports the currency weights of an optimal asset allocation based on a constrained variance minimization routine across the five (seven prior to 1998) main international currencies for Russia, India, China and Brazil. The variance-covariance matrix is estimated with a dynamic conditional correlation multivariate GARCH. We assume currency returns equal to the risk free asset across the main international currencies. Before 1999, EUR is the sum of allocations in the Deutsche mark (DEM), the French franc (FRF) and the Dutch guilder (NLG) (for 1998 equals the allocation to the Deutsche mark (DEM), see also text for more details). For other currency abbreviations see notes in Table 2.

The constraints are based on the trade share with the corresponding developed countries. The trade share is defined as exports plus imports relatively to total (world) trade. The table reports the weights imposing as a constraint that the central bank holds reserves in the currencies of the country's main trade partners at levels equal to $50 \%$ of the share of international trade with each partner. 


\section{Appendix Table A: Currency Returns}

Panel A - Interest Rate Yield

\begin{tabular}{|c|c|c|c|c|c|c|c|c|c|c|c|}
\hline & Dec-95 & Dec-96 & Dec-97 & Dec-98 & Dec-99 & Dec-00 & Dec-01 & Dec-02 & Dec-03 & Dec-04 & Oct-05 \\
\hline USD & $5.43 \%$ & $5.79 \%$ & $5.97 \%$ & $5.10 \%$ & $6.50 \%$ & $6.00 \%$ & $2.44 \%$ & $1.45 \%$ & $1.46 \%$ & $3.10 \%$ & $4.72 \%$ \\
\hline EUR & - & - & - & - & $3.18 \%$ & $4.78 \%$ & $4.09 \%$ & $3.49 \%$ & $2.34 \%$ & $2.29 \%$ & $2.55 \%$ \\
\hline JPY & $1.27 \%$ & $0.84 \%$ & $0.69 \%$ & $0.61 \%$ & $0.26 \%$ & $0.38 \%$ & $0.16 \%$ & $0.10 \%$ & $0.09 \%$ & $0.09 \%$ & $0.11 \%$ \\
\hline GBP & $7.24 \%$ & $6.36 \%$ & $7.28 \%$ & $7.26 \%$ & $5.80 \%$ & $6.53 \%$ & $5.08 \%$ & $4.43 \%$ & $3.88 \%$ & $4.96 \%$ & $4.65 \%$ \\
\hline CHF & $3.27 \%$ & $2.21 \%$ & $1.90 \%$ & $1.76 \%$ & $1.75 \%$ & $3.51 \%$ & $2.84 \%$ & $1.49 \%$ & $0.52 \%$ & $0.82 \%$ & $1.24 \%$ \\
\hline NLG & $9.33 \%$ & $6.06 \%$ & $4.81 \%$ & $4.51 \%$ & $3.75 \%$ & $4.74 \%$ & $4.25 \%$ & $4.52 \%$ & $3.29 \%$ & $2.56 \%$ & $2.07 \%$ \\
\hline DEM & $4.70 \%$ & $3.41 \%$ & $3.56 \%$ & $3.71 \%$ & $3.19 \%$ & $4.79 \%$ & $4.09 \%$ & $3.49 \%$ & $2.33 \%$ & $2.27 \%$ & $2.56 \%$ \\
\hline FRF & $6.47 \%$ & $4.13 \%$ & $3.67 \%$ & $3.72 \%$ & $3.19 \%$ & $4.79 \%$ & $4.08 \%$ & $3.49 \%$ & $2.33 \%$ & $2.27 \%$ & $2.56 \%$ \\
\hline
\end{tabular}

Panel B - Historical Exchange Rate Returns

\begin{tabular}{|c|c|c|c|c|c|c|c|c|c|c|c|}
\hline & Dec-95 & Dec-96 & Dec-97 & Dec-98 & Dec-99 & Dec-00 & Dec-01 & Dec-02 & Dec-03 & Dec-04 & Oct-05 \\
\hline USD & - & - & - & - & - & - & - & - & - & - & - \\
\hline EUR & - & - & - & - & $-15.06 \%$ & $-8.30 \%$ & $-5.77 \%$ & $16.51 \%$ & $18.27 \%$ & $7.72 \%$ & $-11.59 \%$ \\
\hline JPY & $-3.25 \%$ & $-11.19 \%$ & $-11.93 \%$ & $13.91 \%$ & $10.27 \%$ & $-12.02 \%$ & $-14.10 \%$ & $10.28 \%$ & $10.25 \%$ & $4.59 \%$ & $-12.44 \%$ \\
\hline GBP & $-0.59 \%$ & $9.90 \%$ & $-3.96 \%$ & $0.76 \%$ & $-2.57 \%$ & $-9.16 \%$ & $-2.79 \%$ & $10.23 \%$ & $10.36 \%$ & $7.30 \%$ & $-7.32 \%$ \\
\hline CHF & $13.07 \%$ & $-14.83 \%$ & $-8.62 \%$ & $5.92 \%$ & $-14.55 \%$ & $-2.78 \%$ & $-3.05 \%$ & $18.38 \%$ & $11.03 \%$ & $8.72 \%$ & $-11.54 \%$ \\
\hline NLG & $8.00 \%$ & $-7.64 \%$ & $-15.98 \%$ & $6.98 \%$ & - & - & - & - & - & - & - \\
\hline DEM & $8.14 \%$ & $-7.02 \%$ & $-15.46 \%$ & $6.95 \%$ & - & - & - & - & - & - & - \\
\hline FRF & $9.43 \%$ & $-5.67 \%$ & $-14.41 \%$ & $6.87 \%$ & - & - & - & - & - & - & - \\
\hline
\end{tabular}

Panel A reports one-year inter-bank rates. Panel B reports historical excahnge rate returns vis a vis the US dollar.

Currency abbreviations: US dollar (USD); euro (EUR); Swiss franc (CHF); British pound sterling (GBP); Japanese yen (JPY); French franc (FRF); Deutsche mark (DEM) and Dutch guilder (NLG).

Source: Bloomberg. 


\section{Appendix Table B: Currency Composition of External Debt}

\begin{tabular}{|c|c|c|c|c|c|c|c|c|c|}
\hline & 1995 & 1996 & 1997 & 1998 & 1999 & 2000 & 2001 & 2002 & 2003 \\
\hline & \multicolumn{9}{|c|}{ Panel A: Russia } \\
\hline USD & $52.10 \%$ & $49.40 \%$ & $64.60 \%$ & $64.40 \%$ & $71.50 \%$ & $72.30 \%$ & $73.40 \%$ & $69.60 \%$ & $69.10 \%$ \\
\hline JPY & $2.00 \%$ & $1.90 \%$ & $0.20 \%$ & $0.20 \%$ & $0.20 \%$ & $0.10 \%$ & $0.10 \%$ & $0.20 \%$ & $0.40 \%$ \\
\hline GBP & $0.80 \%$ & $0.70 \%$ & $0.30 \%$ & $0.30 \%$ & $0.20 \%$ & $0.10 \%$ & $0.10 \%$ & $0.10 \%$ & $0.10 \%$ \\
\hline CHF & $2.80 \%$ & $2.40 \%$ & $0.10 \%$ & $0.00 \%$ & $0.00 \%$ & $0.00 \%$ & $0.00 \%$ & $0.00 \%$ & $0.00 \%$ \\
\hline DEM & $34.20 \%$ & $37.80 \%$ & $29.00 \%$ & $29.00 \%$ & - & - & - & - & - \\
\hline FRF & $1.40 \%$ & $1.80 \%$ & $0.50 \%$ & $0.00 \%$ & - & - & - & - & - \\
\hline EUR & $35.60 \%$ & $39.60 \%$ & $29.50 \%$ & $29.00 \%$ & $22.40 \%$ & $21.20 \%$ & $20.30 \%$ & $23.60 \%$ & $24.30 \%$ \\
\hline
\end{tabular}

Panel B: India

$\begin{array}{lccccccccc}\text { USD } & 52.40 \% & 56.40 \% & 60.00 \% & 60.60 \% & 61.30 \% & 68.50 \% & 70.40 \% & 73.80 \% & 76.90 \% \\ \text { JPY } & 14.80 \% & 13.30 \% & 12.20 \% & 13.50 \% & 15.30 \% & 11.40 \% & 11.20 \% & 11.80 \% & 13.00 \% \\ \text { GBP } & 4.70 \% & 4.30 \% & 4.10 \% & 3.90 \% & 3.60 \% & 3.70 \% & 3.50 \% & 3.20 \% & 2.80 \% \\ \text { CHF } & 0.90 \% & 0.60 \% & 0.50 \% & 0.40 \% & 0.30 \% & 0.30 \% & 0.40 \% & 0.40 \% & 0.30 \% \\ \text { DEM } & 6.60 \% & 6.00 \% & 5.30 \% & 7.00 \% & - & - & - & - & - \\ \text { FRF } & 2.10 \% & 1.90 \% & 1.80 \% & 0.00 \% & - & - & - & - & - \\ \text { EUR } & 8.70 \% & 7.90 \% & 7.10 \% & 7.00 \% & 6.20 \% & 5.10 \% & 5.50 \% & 5.90 \% & 5.30 \%\end{array}$

Panel C: China

$\begin{array}{lccccccccc}\text { USD } & 58.10 \% & 65.00 \% & 74.60 \% & 72.40 \% & 67.50 \% & 71.40 \% & 74.10 \% & 72.40 \% & 71.20 \% \\ \text { JPY } & 20.70 \% & 15.90 \% & 11.80 \% & 14.80 \% & 17.80 \% & 16.90 \% & 14.50 \% & 15.40 \% & 16.70 \% \\ \text { GBP } & 0.20 \% & 0.20 \% & 0.20 \% & 0.10 \% & 0.10 \% & 0.10 \% & 0.10 \% & 0.10 \% & 0.10 \% \\ \text { CHF } & 0.00 \% & 0.00 \% & 0.00 \% & 0.10 \% & 0.10 \% & 0.10 \% & 0.10 \% & 0.10 \% & 0.10 \% \\ \text { DEM } & 1.70 \% & 1.40 \% & 1.20 \% & 5.20 \% & - & - & - & - & - \\ \text { FRF } & 0.30 \% & 0.30 \% & 0.20 \% & 0.00 \% & - & - & - & - & - \\ \text { EUR } & 2.00 \% & 1.70 \% & 1.40 \% & 5.20 \% & 4.20 \% & 4.20 \% & 4.80 \% & 5.70 \% & 7.20 \%\end{array}$

Panel D: Brazil

\begin{tabular}{lccccccccc} 
USD & $68.20 \%$ & $68.00 \%$ & $68.80 \%$ & $74.60 \%$ & $73.00 \%$ & $71.20 \%$ & $70.60 \%$ & $73.20 \%$ & $77.40 \%$ \\
JPY & $8.60 \%$ & $8.20 \%$ & $7.30 \%$ & $5.90 \%$ & $7.30 \%$ & $7.60 \%$ & $8.80 \%$ & $8.70 \%$ & $7.00 \%$ \\
GBP & $1.80 \%$ & $2.20 \%$ & $2.30 \%$ & $1.70 \%$ & $1.20 \%$ & $1.10 \%$ & $0.90 \%$ & $0.60 \%$ & $0.50 \%$ \\
CHF & $0.30 \%$ & $0.20 \%$ & $0.30 \%$ & $0.20 \%$ & $0.20 \%$ & $0.30 \%$ & $0.30 \%$ & $0.20 \%$ & $0.20 \%$ \\
DEM & $5.10 \%$ & $5.70 \%$ & $5.10 \%$ & $6.40 \%$ & - & - & - & - & - \\
FRF & $6.00 \%$ & $4.90 \%$ & $4.20 \%$ & $0.00 \%$ & - & - & - & - & - \\
EUR & $11.10 \%$ & $10.60 \%$ & $9.30 \%$ & $6.40 \%$ & $4.90 \%$ & $5.80 \%$ & $13.80 \%$ & $12.10 \%$ & $9.90 \%$ \\
\hline
\end{tabular}

The Table reports the currency composition of external debt for Russia, India, China and Brazil.

Currency abbreviations: US dollar (USD), euro (EUR); Swiss franc (CHF); British pound sterling (GBP); Japanese yen (JPY); French franc (FRF); and Deutsche mark (DEM).

Source: World Bank Global Development Finance Database (2005). 


\section{Appendix Table C: Actual Trade Shares}

\begin{tabular}{|c|c|c|c|c|c|c|c|c|c|c|}
\hline & 1995 & 1996 & 1997 & 1998 & 1999 & 2000 & 2001 & 2002 & 2003 & 2004 \\
\hline & \multicolumn{10}{|c|}{ Panel A: Russia } \\
\hline United States & $6.24 \%$ & $7.24 \%$ & $6.56 \%$ & $8.79 \%$ & $8.58 \%$ & $7.80 \%$ & $7.66 \%$ & $6.18 \%$ & $4.79 \%$ & $4.91 \%$ \\
\hline Europe (excl. UK) & $41.23 \%$ & $39.03 \%$ & $41.25 \%$ & $39.06 \%$ & $40.19 \%$ & $42.32 \%$ & $46.99 \%$ & $43.47 \%$ & $44.80 \%$ & $46.81 \%$ \\
\hline Japan & $3.17 \%$ & $3.01 \%$ & $2.85 \%$ & $2.61 \%$ & $2.50 \%$ & $2.44 \%$ & $2.72 \%$ & $1.81 \%$ & $2.24 \%$ & $3.15 \%$ \\
\hline United Kingdom & $3.39 \%$ & $3.34 \%$ & $3.15 \%$ & $3.61 \%$ & $3.41 \%$ & $4.04 \%$ & $3.49 \%$ & $3.21 \%$ & $3.29 \%$ & $3.27 \%$ \\
\hline Switzerland & $3.58 \%$ & $3.46 \%$ & $3.10 \%$ & $3.19 \%$ & $3.68 \%$ & $3.11 \%$ & $1.60 \%$ & $3.78 \%$ & $3.33 \%$ & $3.59 \%$ \\
\hline Germany & $10.17 \%$ & $9.26 \%$ & $9.58 \%$ & $9.71 \%$ & $10.10 \%$ & $9.59 \%$ & $11.63 \%$ & $9.52 \%$ & $9.70 \%$ & $10.14 \%$ \\
\hline France & $2.09 \%$ & $2.24 \%$ & $2.34 \%$ & $2.65 \%$ & $2.33 \%$ & $2.27 \%$ & $2.71 \%$ & $2.96 \%$ & $3.07 \%$ & $3.05 \%$ \\
\hline Netherlands & $3.89 \%$ & $3.36 \%$ & $4.19 \%$ & $4.23 \%$ & $4.10 \%$ & $3.71 \%$ & $3.94 \%$ & $5.41 \%$ & $5.20 \%$ & $7.04 \%$ \\
\hline
\end{tabular}

\section{Panel B: India}

United States

Europe (excl. UK)

Japan

United Kingdom

Switzerland

Germany

France

Netherlands

13.30\% $13.70 \%$ 13.84\% $14.19 \%$ 13.94\% $13.16 \%$ 12.95\% $13.20 \% \quad 12.03 \% 10.74 \%$

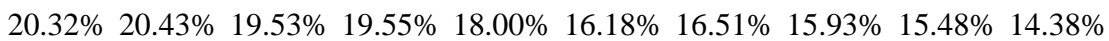
$\begin{array}{llllllllll}6.71 \% & 6.16 \% & 5.40 \% & 5.41 \% & 5.01 \% & 4.07 \% & 3.98 \% & 3.37 \% & 3.11 \% & 2.76 \%\end{array}$ $\begin{array}{llllllllll}5.48 \% & 5.79 \% & 5.94 \% & 5.94 \% & 5.58 \% & 5.69 \% & 5.08 \% & 4.70 \% & 4.45 \% & 3.88 \%\end{array}$ $\begin{array}{lllllllllll}1.62 \% & 1.78 \% & 3.46 \% & 4.22 \% & 3.61 \% & 3.70 \% & 0.71 \% & 2.61 \% & 2.59 \% & 3.25 \%\end{array}$ $\begin{array}{lllllllllll}7.00 \% & 6.72 \% & 5.99 \% & 5.42 \% & 4.39 \% & 3.92 \% & 4.14 \% & 3.97 \% & 3.87 \% & 3.57 \%\end{array}$ $\begin{array}{llllllllll}2.12 \% & 2.18 \% & 2.04 \% & 2.06 \% & 1.92 \% & 1.79 \% & 2.04 \% & 1.91 \% & 1.73 \% & 1.63 \%\end{array}$ $\begin{array}{llllllllll}1.79 \% & 2.03 \% & 1.69 \% & 1.63 \% & 1.58 \% & 1.43 \% & 1.30 \% & 1.29 \% & 1.28 \% & 1.23 \%\end{array}$

\section{Panel C: China}

United States Europe (excl. UK) Japan

United Kingdom Switzerland Germany

France Netherlands

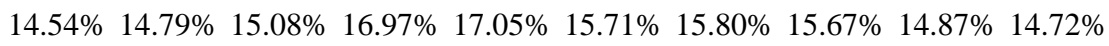

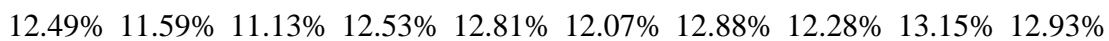
20.44\% $20.71 \% \quad 18.71 \% \quad 17.90 \% \quad 18.35 \% \quad 17.53 \% \quad 17.22 \% \quad 16.42 \% \quad 15.69 \% \quad 14.54 \%$ $\begin{array}{llllllllll}1.69 \% & 1.75 \% & 1.78 \% & 2.03 \% & 2.18 \% & 2.09 \% & 2.02 \% & 1.83 \% & 1.69 \% & 1.71 \%\end{array}$ $\begin{array}{lllllllllll}0.48 \% & 0.48 \% & 0.46 \% & 0.44 \% & 0.47 \% & 0.47 \% & 0.47 \% & 0.43 \% & 0.42 \% & 0.45 \%\end{array}$ $\begin{array}{lllllllllll}4.88 \% & 4.54 \% & 3.90 \% & 4.43 \% & 4.47 \% & 4.15 \% & 4.60 \% & 4.48 \% & 4.92 \% & 4.69 \%\end{array}$ $\begin{array}{llllllllll}1.60 \% & 1.43 \% & 1.72 \% & 1.86 \% & 1.86 \% & 1.62 \% & 1.56 \% & 1.35 \% & 1.58 \% & 1.53 \%\end{array}$ $\begin{array}{llllllllll}1.44 \% & 1.54 \% & 1.69 \% & 1.85 \% & 1.78 \% & 1.67 \% & 1.71 \% & 1.71 \% & 1.81 \% & 1.86 \%\end{array}$

\section{Panel D: Brazil}

United States

Europe (excl. UK) Japan

United Kingdom

Switzerland

Germany

France

Netherlands

\begin{abstract}
20.10\% 20.93\% 20.64\% 21.68\% 23.21\% 22.78\% 23.86\% 24.06\% 21.74\% $19.79 \%$ $24.88 \% 23.63 \%$ 23.64\% 25.55\% 25.72\% 22.16\% 23.75\% 23.02\% 22.30\% 21.81\% $\begin{array}{llllllllll}6.64 \% & 5.70 \% & 5.76 \% & 5.05 \% & 4.88 \% & 4.71 \% & 4.45 \% & 4.17 \% & 4.00 \% & 3.55 \%\end{array}$ $\begin{array}{lllllllllll}2.38 \% & 2.53 \% & 2.37 \% & 2.61 \% & 2.70 \% & 2.35 \% & 2.54 \% & 2.89 \% & 2.54 \% & 2.16 \%\end{array}$ $\begin{array}{lllllllllll}1.15 \% & 1.21 \% & 1.01 \% & 1.05 \% & 1.03 \% & 1.53 \% & 1.26 \% & 1.28 \% & 1.07 \% & 0.92 \%\end{array}$ $\begin{array}{lllllllllll}7.28 \% & 6.88 \% & 6.76 \% & 7.66 \% & 7.50 \% & 6.08 \% & 6.47 \% & 6.57 \% & 6.11 \% & 5.76 \%\end{array}$ $\begin{array}{llllllllll}2.53 \% & 2.24 \% & 2.44 \% & 3.01 \% & 3.32 \% & 3.13 \% & 3.29 \% & 3.07 \% & 2.91 \% & 2.85 \%\end{array}$ $\begin{array}{lllllllllll}3.53 \% & 3.91 \% & 3.81 \% & 3.08 \% & 3.15 \% & 2.93 \% & 2.86 \% & 3.36 \% & 3.78 \% & 3.95 \%\end{array}$
\end{abstract}

The Table reports the share of trade (exports plus imports) of Russia, India, China and Brazil against the main industrial countries relatively to the total volume of international trade.

Source: IMF Direction of Trade Statistics (2005). 